\title{
Antibody-Conjugated Nanoparticles for Biomedical Applications
}

\author{
Manuel Arruebo, ${ }^{1}$ Mónica Valladares, ${ }^{2}$ and África González-Fernández ${ }^{2}$ \\ ${ }^{1}$ Aragon Nanoscience Institute (INA), University of Zaragoza, 50009 Zaragoza, Pedro Cerbuna 12, Spain \\ ${ }^{2}$ Immunology Area, Faculty of Biology, University of Vigo, Campus As Lagoas-Marcosende, 36310 Vigo, Pontevedra, Spain \\ Correspondence should be addressed to Manuel Arruebo, arruebom@unizar.es
}

Received 19 June 2009; Accepted 2 September 2009

Recommended by Maryam Tabrizian

Nanoscience and Nanotechnology have found their way into the fields of Biotechnology and Medicine. Nanoparticles by themselves offer specific physicochemical properties that they do not exhibit in bulk form, where materials show constant physical properties regardless of size. Antibodies are nanosize biological products that are part of the specific immune system. In addition to their own properties as pathogens or toxin neutralizers, as well as in the recruitment of immune elements (complement, improving phagocytosis, cytotoxicity antibody dependent by natural killer cells, etc.), they could carry several elements (toxins, drugs, fluorochroms, or even nanoparticles, etc.) and be used in several diagnostic procedures, or even in therapy to destroy a specific target. The conjugation of antibodies to nanoparticles can generate a product that combines the properties of both. For example, they can combine the small size of nanoparticles and their special thermal, imaging, drug carrier, or magnetic characteristics with the abilities of antibodies, such as specific and selective recognition. The hybrid product will show versatility and specificity. In this review, we analyse both antibodies and nanoparticles, focusing especially on the recent developments for antibody-conjugated nanoparticles, offering the researcher an overview of the different applications and possibilities of these hybrid carriers.

Copyright (C) 2009 Manuel Arruebo et al. This is an open access article distributed under the Creative Commons Attribution License, which permits unrestricted use, distribution, and reproduction in any medium, provided the original work is properly cited.

\section{Introduction}

According to Lux Research, in 2006, governments, corporations, and venture capitalists worldwide spent $\$ 12.4$ billion on nanotechnology research and development up almost $30 \%$ from 2005. By 2014, Lux estimates $\$ 2.6$ trillion or about $15 \%$ of the total global output in manufactured goods will incorporate nanotechnology [1].

As many other industries, Nanoscience and Nanotechnology have also found their ways into the fields of Biotechnology and Medicine. The estimated global production for engineered nanomaterials applied in Biotechnology will reach by $20101 \mathrm{Tn} /$ year, and by 2020 that value will increase to $10 \mathrm{Tn} /$ year [2]. Nanotechnology is already present in many commercialized medical products. However, many of them are not available directly to the consumer, instead, they are used for research purposes [1].

Nanoparticles by themselves offer specific physicochemical properties that they do not exhibit in bulk form where the materials show constant physical properties regardless of their sizes. Those properties make nanoparticles applicable in many biomedical applications. Compared to microparticles, nanoparticles show larger surface area to volume ratio, which implies that they may render higher binding efficiencies. Also, larger particles may block specific binding regions on cells hindering cell receptors. However, some physical properties are enhanced by using microparticles compared to nanoparticles. For instance, if they are magnetic, larger particles are preferable due to their faster response to a magnetic gradient. However, for any in vivo biomedical application nonbiodegradable microparticles will be excluded due to their potential accumulation in the spleen and the kidneys due to the size exclusion capability of those organs.

The conjugation of different moieties to the nanoparticles widens their application fields and provides them with new or enhanced properties. A range of biomoieties can be conjugated to the nanoparticles including low molecular weight ligands (folic acid, thiamine, dimercaptosuccinic acid), peptides (RGD, LHRD, antigenic peptides, internalization peptides), proteins (BSA, transferrin, antibodies, lectins, cytokines, fibrinogen, thrombin), polysaccharides (hyaluronic acid, chitosan, dextran, oligosaccharides, heparin), polyunsaturated fatty acids (palmitic acid, phospholipids), DNA, plasmids, siRNA, and so forth. 
Most of the mentioned moieties show proven selectivity and clear advantages such as the ability of crossing biological membranes. For instance, certain regions of the TAT-peptide known as protein transduction domains are able to pass biological membranes by mechanisms that are independent of transporters and receptor-mediated endocytosis. The susceptibility of the peptides to be denatured by proteases and their short vascular circulation lifetimes are their main drawbacks. Synthetic molecules of DNA or RNA known as aptamers are also able to recognize specific proteins. The main advantage of using aptamers compared to antibodies is their in vitro selection process without using animals, in addition to their small size, lack of immunogenicity, and ease of isolation. The main disadvantages of using aptamers compared to antibodies are the high cost to generate them especially in large quantities and their susceptibility to enzymatic degradation.

The conjugation of nanoparticles with antibodies combines the properties of the nanoparticles themselves with the specific and selective recognition ability of the antibodies to antigens. Also, the improvement in the cellular uptake as well as the major intracellular stability may be two of the major advantages of using antibody conjugated nanoparticles.

In this review we analyze the developments reached by using antibody-conjugated nanoparticles, offering to the reader a general scope of the different applications and possibilities of those hybrid carriers. In addition, we describe briefly the conjugation possibilities for those interested in the specific chemistry involved. Nanoparticles conjugated to peptides and proteins other than antibodies have not been considered in this review. Conjugated dendrimers, dendritic polymers, quantum dots, carbon nanotubes, and micelles have been excluded in this review because each one is deserving its own.

\section{Antibodies: Structure and Function}

Immunoglobulins or antibodies are a group of glycoproteins that constitute one of the most important specific defence mechanisms in vertebrate animals. All of them have a very similar structure in a Y form (Figure 1) of bifunctional molecules with two identical domains for antigen recognition (Fab fragment), and two identical domains with effector functions ( $\mathrm{Fc}$ fragment). The antigen-binding region is highly specific, and varies among the antibodies. Thousands of millions of different antibodies can be generated, each one with a distinct specificity.

Antibodies have two identical light chains of $24-25 \mathrm{kD}$ (either, $\kappa$ or, $\lambda$ ) and two heavy chains, also identical, of 55$70 \mathrm{kD}(\gamma, \varepsilon, \delta, \alpha$, or $\mu)$ bound by disulphur bridges [3$6]$. The type of immunoglobulin generated depends on the type of heavy chain and, therefore, in vertebrate animals five classes or isotypes of immunoglobulins (IgG, IgE, IgD, IgA, and IgM) can be distinguished, each one with a distinct functionality. In addition to the disulphur bridges between the chains, there are intracatenary disulphur bridges that provide stability to the molecule [7]. The light chain (L) is formed by two domains of around 100 residues, known as the variable domain $\left(\mathrm{V}_{\mathrm{L}}\right)$, at its aminoterminal end, and

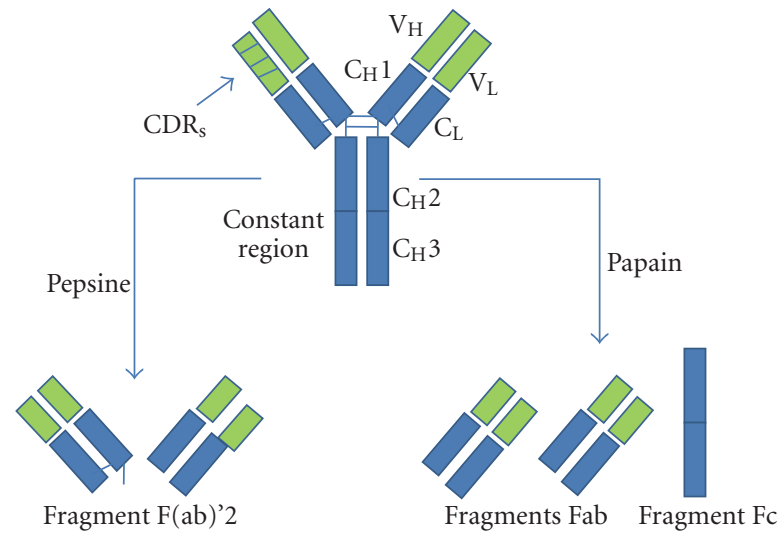

Figure 1: Structure of an Ig molecule carrying two heavy and two light chains linked by disulphur bridges. The products resulting from the action of enzymes (papain and pepsin) are shown.

the constant domain $\left(\mathrm{C}_{L}\right)$. The heavy chain $(\mathrm{H})$ contains a variable domain $\left(\mathrm{V}_{\mathrm{H}}\right)$ and three or four constant domains $\left(\mathrm{C}_{\mathrm{H}} 1, \mathrm{C}_{\mathrm{H}} 2, \mathrm{C}_{\mathrm{H}} 3, \mathrm{C}_{\mathrm{H}} 4\right)$, depending on the isotype [8]. The variable regions are the zones of the molecule involved in antigen binding, where the most divergent hypervariable regions, or complementary determining regions (CDR), are three in the VL domain and three in the VH domain [9, 10]. These regions are separated by structural regions called framework (FRW), which have highly conserved sequences.

Immunoglobulins (Igs) are found as membrane receptors in B lymphocytes, which are a subpopulation of leukocytes. After activation mediated by antigen (virus, bacteria, parasite), and in collaboration with other immune cells (such as T lymphocytes), the B lymphocytes become plasma cells secreting antibodies. The antibodies can then be released from the cell and have different effector functions.

Among their most important functions are the following:

(1) neutralization and blocking of pathogens and toxins;

(2) activation of complement: the IgM and IgG activate a proteolytic cascade, which leads eventually to the opening of pores in the membrane of the pathogens or target cells;

(3) opsonization and Phagocytosis: the IgG are the main type of antibodies capable of facilitating phagocytosis of pathogens, by binding to receptors of macrophages and dendritic cells;

(4) antibody-dependent cellular cytotoxicity (ADCC), natural Killer (NK) cells, and macrophages lyse cells in the presence of antibodies directed at target cells, to achieve this, the Fc portion of the antibody binds to the target cells, which secrete granular proteins that mediate in cytolytic functions;

(5) responses to parasites and allergic responses: the $\mathrm{IgE}$ is involved in allergic responses through the activation of mastocytes, which release their charged granules (of histamine, prostaglandins, etc.). It also participates in the elimination of parasites, with the help of eosinophils; 
(6) Mucosal protection: the IgA undertakes mucosal protection (respiratory, digestive) and is present in secretions, such as breast milk.

\section{Monoclonal Antibodies}

In 1975, César Milstein and George Köhler immortalized antibody-producing B cells by their fusion with tumoral cells to obtain hybrid cells or hybridomas (Figure 2).

These cells are capable of producing a single type of antibody in large quantities; as they derive from a single cell that divides into identical cells, the antibody that they generate is known as a monoclonal antibody. The two researchers were awarded the Nobel Prize for Medicine or Physiology in 1984, for making possible the use of antibodies directed against specific targets in large numbers, which has been a revolution in many fields of knowledge, especially biomedicine.

The production of monoclonal antibodies starts with the repeated immunization of laboratory animals (generally mice or rats), which are injected at intervals with the antigen, against which it is intended to develop the corresponding antibody. After several immunizations, when the B lymphocytes begin to proliferate in response to the antigen, the activated lymphoid organ is removed, generally the spleen, which has become a primary source of antigen-specific B lymphocytes. Subsequently, the lymphocytes are fused with mouse B tumoral cells (myelomas), which are capable of proliferate indefinitely when they are cultivated in vitro under specific conditions. However, they lack some of the enzymes required for nucleotide synthesis and, also, are unable to secrete their own endogenous Ig. The result is a hybridoma, a cell that combines the capacity of the B lymphocyte to produce a specific antibody with the capacity of the myeloma cell to reproduce indefinitely. Hybridomas can be frozen and thawed, allowing them to be kept for an indefinite time. This means, among other attributes, the availability of an inexhaustible source of specific and homogenous antibodies.

Above all, monoclonal antibodies (mAbs) have meant a revolution in the field of clinical diagnosis, for the purification of products (coagulation factors, interferon), for the design of new technologies, and also they have been actively introduced into the treatment of various diseases. In diagnosis and research, they have helped to increase knowledge of a large variety of molecules, to define the stages of leukaemia, to identify tumours and transcription factors, to define species, to quantify hormones, to study blood groups, to characterize infectious agents, besides an enormous number of targets that are now known thanks to monoclonal antibodies. In order to standardize the names given to the antibodies produced against the cell membrane, especially that of leukocytes, an agreement has been reached to group under the same cluster or number all those antibodies that recognize the same membrane molecule. The cluster differentiation (CD) concept has emerged as a consequence of this agreement, in which, to date, more than 300 different molecules have been classified. These are revised and updated every four years at an international CD

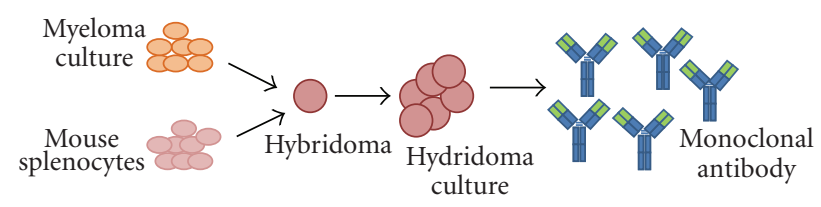

Figure 2: Schematic description of the synthesis of monoclonal antibodies.

workshop. As examples, a helper $\mathrm{T}$ lymphocyte is known as CD3+ CD4+ for presenting those membrane molecules, which are recognized by specific antibodies; a cytotoxic $\mathrm{T}$ lymphocyte is CD3+ CD8+, and a B lymphocyte is CD19+ $\mathrm{CD} 20+$. These and many other markers have improved the study of cell subpopulations, have allowed better definition of differentiation states, and have helped in the identification of leukaemia, lymphomas, breast tumours, and so forth.

In addition to the antibodies directed against molecules of the cell membrane, there is a long list of antibodies that recognize transcription factors, pathogenic agents, hormones which are now essential in the laboratories of Immunology, Microbiology, Physiology, Virology, Pathology, Cell Biology, and many others, and are mainly used in diagnostic techniques, such as ELISA, immunofluorescence, inmunohistochemistry, Western blot, immunochromatography or lateral flow, nephelometry, agglutination and precipitation methods, as some examples.

\section{Monoclonal Antibodies in Therapy}

The enormous therapeutic potential of mAbs was initially undermined by certain "technical" difficulties, which explain the long gap from obtaining mAbs in sufficiently large quantities in 1975 to the beginning of their clinical application. This started in 1986, with the use of the anti-CD3 antibody for avoiding rejection in heart transplantation, and it was not until 1997 that mAbs entered in the field of onco-haematology, when the US Food and Drug Administration (FDA) approved Rituximab (a humanized anti-CD20 monoclonal antibody) as the first antibody for antitumoral therapy (http://www.fda.gov/).

In antitumoral therapy, when compared to conventional chemotherapeutic agents, mAbs are high molecular weight proteins with slow distribution kinetics and a limited tissuepenetrating ability. However, their enormous advantage is that they are specific, thereby minimizing secondary effects, as they would be directed at their tumoral targets (antigens) without affecting or with only minimum effect on healthy tissues. The capacity of monoclonal antibodies to penetrate tumours or to access inflammation sites is low $[11,12]$. In particular, in antitumoral therapy, antigen expression and blood irrigation are the factors limiting the effectiveness of the mAbs. Therefore, for optimal effectiveness, the target antigen should be tumour-specific, intensely expressed, and its expression should not be susceptible to being reduced. The mAbs requirements for achieving a maximum response would be: a long half-life, the power to penetrate, not to induce an immune response, and a maximum cytotoxic effectiveness [13]. 
4.1. First-Generation Monoclonal Antibodies. The first clinical trials were carried out with mouse or rat mAbs against receptors on the surface of human cells, such as T lymphocytes (anti-CD3), B lymphocytes (anti-CD20), and so forth. However, given that the sequences of these antibodies are murine, their efficacy was affected by the production of Human Anti-Mouse or Anti-Rat Antibodies, HAMA or HARA, respectively, in patients who received this therapy. The generation of this immune response is the main impediment to therapeutic success with murine mAbs, as they can cause important allergic reactions in continuous treatments, or a reduction in their therapeutic efficacy. Further limitations are their short half-life and the difficulty of the interaction between murine antibodies and human cells of the immune system.

In an attempt to partially resolve this problem, antibody fragments were used rather than an intact antibody. Specifically, the use of Fabs (fragment antigen binding) should be mentioned, which include the variable regions of both the heavy chains (Hv) and the light chains (Lv), as well as the first constant domain of both chains (CH and CL). These fragments do not include the $\mathrm{Fc}$ region, and this means the immunogenicity that can be produced is lower than if an intact antibody were used. The Fab fragments, which provide the specificity of antibody, could be used for sterically blocking or impeding the function of the target antigen, or for modulating cellular function (by the binding of a target antigen capable of translating intracellular signal). However, the lack of the Fc fragment in the antibody impedes the various functions specific to this region (to facilitate phagocytosis, complement activation, antibody-dependent cellular cytotoxicity), therefore, depending on the desired aim, the therapy could become useless.

4.2. Second-Generation Monoclonal Antibodies. The HAMA or HARA responses could be avoided if the monoclonal antibodies were completely human. However, different technical difficulties did not allow obtaining completely human monoclonal antibodies using the traditional cell fusion technique for producing hybridomas. In the mid 1980s, molecular biology techniques provided a very important tool, which allowed the production of what have been called "second-generation monoclonal antibodies" or "recombinant antibodies" [14]. These antibodies are produced by immortalization of the genes codifying the monoclonal antibody molecule, instead of immortalizing the monoclonal antibody-producing cell.

Two characteristics of these proteins have facilitated the conceptual modelling, design and engineering of Ig-based artificial molecules. At the genetic level, the structural genes that codify the Igs are suitable for working in Molecular Biology. These genes are organized as discrete exons, which correspond to complete domains in the protein, separated by intronic regions. Therefore, it is simple to manipulate the intronic sequences by adding changes that allow the introduction into the gene of new sequences in specific and previously selected locations, without any risk of altering the coding sequence present in the exons. Similarly, at protein level, the structural-functional organization of the
Igs is structured into discrete modules with variable $(\mathrm{V})$ and constant domains $(\mathrm{C})$ in both the heavy $(\mathrm{H})$ and light $(\mathrm{L})$ chains, which has made the achievement of these objectives easier.

Hence, it is possible to clone two regions, $V_{H}$ and $V_{L}$, responsible for a required specificity, and assemble them as a functional antibody in any class or subclass of human Ig [15]. A considerable number of expression systems are currently available for this purpose [16]. Several eukaryotic cell lines adequately support all the necessary and associated processes for the expression, synthesis, assembly and post-translation modifications of the recombinant antibodies [17].

In prokaryote organisms, detailed knowledge of the genome, architecture and life cycle of filamentous bacteriophages $[18,19]$ and of the lambda phage $[20,21]$ has also allowed the efficient expression of the DNA codifying for antibodies in these phage and subsequent infection of bacteria $[22,23]$. Thanks to these phage, it has been possible to generate very large antibody repertoires (libraries) [24, 25] and, therefore, it has become possible to artificially imitate the selection strategy employed by the humoral immune system. Currently, this technology offers one of the most powerful ways for creating artificial antibodies with reduced immunogenicity and for the creation of antibody repertoires in combinatorial gene banks with a similar size to the natural repertoires.

4.2.1. Complete Antibody Molecules. These antibodies are very similar to natural ones, with the two structural elements present, thereby permitting the functionality of the molecule with Fab and Fc portions. Primatized, humanized and chimeric antibodies (Figure 3 ) are included under this heading. A chimeric antibody is a combination of sequences from different species; the most common ones are those with a full human sequence except for the variable regions, which are of murine origin. In humanized antibodies, only some small regions of the variable domains (called hypervariable regions or CDRs) belong to the original species, and the remainder have human sequences. Finally, primatized antibodies are composed of variable regions of the primate and constant regions of human origin [26].

This variety of antibodies requires a new nomenclature for identifying their origin. Hence, the suffix-momab indicates murine origin; the suffix-ximab implies that it is a chimeric monoclonal antibody; and -zumab designates humanized monoclonal antibodies. In many cases, a further complication is the small case letters that precede them, such as $\mathbf{h}$ or hu (humanized), $\mathbf{r}$ (recombinant), or c (chimeric).

Chimeric Antibodies. A chimeric antibody is an artificial molecule where the constant portions of the heavy and light chains are from a human Ig, and the variable regions, $\mathrm{V}_{\mathrm{H}}$ and $\mathrm{V}_{\mathrm{L}}$, are obtained from a mouse or rat monoclonal antibody. The aim of this construction is to reduce the immunogenecity of the mouse or rat antibodies, without affecting the specificity of the original antibody. The most immunogenic regions of the antibody molecule are associated to the constant portion of the molecule, the Fc portion [27]. These regions are replaced by equivalents of human 


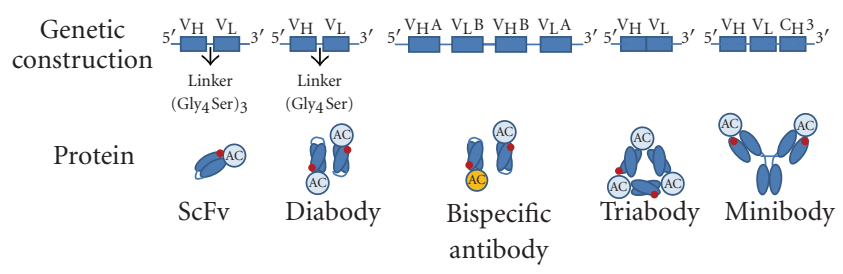

FIgURe 3: Genetic construction of different antibody fragments.

origin so that the resulting molecule is less "strange" for humans and, therefore, makes its use in vivo easier for prophylaxis and treatment of human diseases. The term "chimeric," derived from chimera, the mythical monster born from the union of Typhon and Echidna with the head of a lion, the body of a goat and the tail of a serpent, was chosen for this type of antibody, as they originate from two different species (humans and mice).

Chimerization developed by Morrison et al. [28] and Boullianne et al. [29] in the mid-1980s was based on the cloning of murine $\mathrm{V}_{\mathrm{H}}$ and $\mathrm{V}_{\mathrm{L}}$ genes and their insertion in eukaryotic expression vectors. Previously, the coding genes of the constant portion of the human heavy and light chains had been incorporated into these eukaryotic expression vectors, with approximately $34 \%$ of the sequence still being murine and the rest of human origin $[27,30]$. These vectors are finally transfected in a stable form into a selected cell line. The reverse transcriptase-polymerase chain reaction (RT-PCR) technique is used for cloning the $\mathrm{V}_{\mathrm{H}}$ and $\mathrm{V}_{\mathrm{L}}$ genes. Messenger or total RNA obtained from a secretor hybridoma of the required specificity is used as mould, and complementary oligonucleotides at the $3^{\prime}$ and $5^{\prime}$ ends/termini of each gene as initiators. It has been demonstrated that the protein product generated by these constructions is capable of recognizing and binding to the antigen, and efficiently mediating in effector functions, such as complement activation and interaction with $\mathrm{Fc}$ receptors, while showing a reduced immunogenicity [31]. Currently, nearly half of the antibodies approved for therapy by the FDA are of the chimeric type [32].

Humanized Antibodies. Unfortunately, some chimeric molecules are still able to induce a humoral immune response when administered to humans. Important Human Anti-Chimeric Antibody (HACA) responses have been found in $40 \%$ of the products used in humans [32]. Efforts to reduce the immunogenicity of antibodies led to the creation, between 1988 and 1991, of "humanized" antibodies. This technology includes a variety of procedures, such as CDR grafting, $\mathrm{Ab}$ reshaping, and $\mathrm{Ab}$ resurfacing/veneering [3335], based on the substitution of the residues of the anchor domains or "Framework" of the murine variable region by human sequences, until only the three hypervariable regions (5-10\% of the sequence) are of murine origin and all the rest of human origin [36]. The problem is that manipulation of the murine hypervariable regions and their insertion into the human anchor domains, generally entails a reduction in antibody affinity $[33,37]$, as its three-dimensional configuration is altered, but humanized antibodies have the advantages of being less immunogenic, more effective and have a longer half-life (between 3 and 24 days) than chimeric antibodies (between 4 and 15 days) $[11,13]$.

Primatized Antibodies. Primatized antibodies are the result of a chimeric structure of human and primate origin, as a nearly exact copy of the human antibody with reduced immunogenicity and the possibility of using repeated doses and a long-term therapy [26]. The variable regions come from Macaca fascicularis (Macaca irus, Cynomolgus macaque), which are nearly indistinguishable from the human equivalents, and the constant regions are of human origin. Keliximab and Clenoliximab are examples of this type of antibody, both in a trial phase [38, 39], and are directed against a molecule present in helper $\mathrm{T}$ lymphocytes. Lumiliximab is another antibody of this type, an anti-CD23 antibody that inhibits the production of IgE and is a potent therapy in allergic processes [40].

4.2.2. Recombinant Molecules Derived from Antibodies. Molecular biology has also been utilized (Figure 3) to develop a more heterogeneous group of new proteins, all based on the structure of antibodies, either as autonomous recombinant entities (Fab type fragments, Fv of the simple chain form of scFv, diabodies, triabodies, bispecifics, minibodies, phage antibodies), or as fusion proteins or conjugated antibodies, in which the Fc or the Fab portion is combined with new properties that have a toxin, an enzyme, a cellular receptor, a cytokine, and so forth.

Antibody Fragments. Antibody fragments offer some advantages over intact antibodies in therapy, especially against solid tumours. The speed of penetration by a fragment versus an intact molecule is the most remarkable advantage. In 1988, Jain [11] established that an intact molecule of IgG took 54 hours to penetrate $1 \mathrm{~mm}$ into a solid tumour, while a Fab fragment managed the same distance in 16 hours.

Although the expression of chimeric and humanized antibodies has been carried out in eukaryotic cells, bacteria (Escherichia coli) have been used more frequently for the production of recombinant antibody fragments [41]. The expression of antibody fragments in the periplasm of bacteria follows an assembly pathway similar to that of the production of conventional antibodies in the endoplasmic reticulum of a B cell [41]. This allows producing molecules in a small volume and in a subcellular compartment that is relatively free from active proteolytic enzymes.

Single Chain Fv ( $s c F v$ ). Two studies published in 1988 showed the production in $E$. coli of a recombinant version of the $\mathrm{Fv}$ fragment in which the $\mathrm{V}_{\mathrm{H}}$ and $\mathrm{V}_{\mathrm{L}}$ domains were bound physically by a small and flexible peptide linker $[42,43]$. This linker, of around 15 amino acids, has the necessary length and flexibility to permit an adequate spatial orientation of the $\mathrm{V}_{\mathrm{H}}$ and $\mathrm{V}_{\mathrm{L}}$, domains, generating a functional $\mathrm{Fv}$ of around $25 \mathrm{kD}$. Such constructions were called single chain $\mathrm{Fv}(\mathrm{scFv})$, which are more stable than conventional $\mathrm{Fv}$ and conserve the capacity of recognizing and 
binding to the antigen. Their small size means that their renal clearance is rapid; therefore, they are potentially useful as radioactively-marked molecules $[44,45]$.

The establishment of antibody gene banks has allowed the generation of antibody repertoires of such size and diversity that it is possible to presume that all the natural repertoire can be found within them. The use of the lambda bacteriophage and, subsequently, of filamentous bacteriophages as vectors has been the key in the construction of these enormous versatile gene banks.

Diabodies, Bispecific Antibodies, and Triabodies. The Fab and $\mathrm{svFv}$ fragments can have a limited use for certain applications in which a high affinity is required, as they are molecules that have only one antigen combination site (univalents). Multivalent versions of these fragments should show a functional affinity or higher avidity. In addition, recombinant antibodies that combine two distinct specificities are particularly attractive for certain applications, such as immunodiagnostics and immunotherapy, and several strategies have been employed for producing dimers or polymers of recombinant antibodies. Although some use the chemical crossover of two individual fragments [46, 47], previously prepared and separately purified, but with the disadvantage of low yield and problems in the purification of the required fragment, other more effective strategies have recently been developed, based on recombinant DNA techniques. One of these strategies is based on the scFv construction in which the linker is smaller than the original, which makes impossible the formation of a functional $\mathrm{Fv}$ between the $\mathrm{V}_{\mathrm{H}}$ and $\mathrm{V}_{\mathrm{L}}$ domains in the same molecule. This leads to the interaction of two molecules of the $\mathrm{scFv}$, forming a dimer, which has two antigen-combination sites. If the $\mathrm{V}_{\mathrm{H}}$ and $\mathrm{V}_{\mathrm{L}}$ domains have the same specificity, the product obtained is a bivalent homodimer known as a Diabody [48]. Using the same technique, it is possible to produce recombinant molecules with two different specificities, called Bispecific Antibodies [49]. If the polypeptide that serves as the linker between the $\mathrm{V}_{\mathrm{H}}$ and $\mathrm{V}_{\mathrm{L}}$ domains is completely eliminated and both regions are expressed as a continuous polypeptide, the result is the formation of a functional trimer with the ability to bind to three antigen determinants. These fragments have been called Triabodies [50, 51].

Minibodies. In 1994, Tramontano et al. [52] described the design of an artificial polypeptide with a structure based on the IgV domain, which was called a Minibody. This polypeptide has a length of 61 amino acid residues and adopts a conformation that has an antigen-binding ability, and appears to show excellent pharmacokinetic properties in tumours $[53,54]$.

"Camelid" Antibodies. The presence of antibody molecules composed of heavy chain dimers devoid of the light chain was discovered in camel blood $[55,56]$. This motivated a research group to create antibodies with a single $\mathrm{V}_{\mathrm{H}}$ domain. To simulate the structure of the camel antibodies, mutations were introduced into a pre-selected human $\mathrm{V}_{\mathrm{H}}$ domain, and those changes were sufficient to prevent the interaction of the mutated human $\mathrm{V}_{\mathrm{H}}$ with the homologous human $\mathrm{V}_{\mathrm{L}}$. Subsequently, the sequence of the third hypervariable region of the $\mathrm{V}_{\mathrm{H}}$ domain was "randomized" and the repertoire obtained was expressed as a gene bank of recombinant filamentous phage in E. coli. It was, thereby, possible to obtain soluble $\mathrm{V}_{\mathrm{H}}$ domains capable of high-affinity antigen binding [57].

Fusion Proteins or Immunoconjugates. Recombinant DNA technology has made possible the creation, design and production of molecules called fusion proteins, in which different functional and/or structural motifs are combined, derived from two or more natural proteins. There are an important number of fusion proteins, where fragments of different antibody molecules are combined with toxins, cytokines, adhesion molecules, components of the extracellular matrix, hormones, growth factors, CD molecules, cellular receptors, and lipids.

Aptamers. Both oligonucleotide (sequences of oligonucleotides) and peptide (variable peptide sequence inserted into a constant scaffold protein) aptamers are also being tested for their potential therapeutic use [58]. They have the advantages that they are smaller than antibodies and easier to design.

\section{Human Monoclonal Antibodies}

The advantages of being able to use fully human monoclonal antibodies can be summarized as follows.

(i) To reduce the possibility of an immune response: the administration of human immunoglobulins will not lead to the development of strong immune responses, such as those seen against mouse Igs, although antiidiotypic responses could appear.

(ii) The repertoire of antigenic epitopes is recognized in a distinct way among the different species.

(iii) Human immunoglobulins interact better with human effector systems, Fc receptors, opsonization, and so forth, than antibodies of murine origin.

(iv) There are differences associated to the distinct patterns of glycosylation among different species, which can affect the effectiveness of the antibody as a therapeutic agent.

(v) The half-life of these antibodies is longer. Human antibodies have a half-life of 11-24 days.

5.1. Immortalization of Human B Lymphocytes. The production of human monoclonal antibodies with the classic hybridoma technique, using human myelomas or hybrid fusions between human B-cells and mouse myeloma cells (heteromyelomas), encountered numerous problems, above all the instability of the hybridomas and the low production of antibodies. This made the search for new methods to obtain totally human antibodies imperative. 
The first efforts were made by Steinitz in 1997, by the tumoral transformation of human B lymphocytes using the Epstein-Barr virus (EBV), a human oncogenic herpes virus responsible for infectious mononucleosis and Burkitt's lymphoma. In vitro studies have shown that infection with this virus induces the activation and growth of B lymphocytes, with antibody secretion, although in small quantities.

5.2. Transfection of Mammalian Cells. Another possibility is the production of completely human monoclonal antibodies, by cloning both the heavy and light chains, and their subsequent transfection to mammalian cells [59]. The perfection of the expression vectors, the identification within the genome of appropriate integration sites and the capacity to accumulate biomass mean that the cell culture systems produce $1-2 \mathrm{~g} / \mathrm{L}$ of antibodies [60]. The mouse myeloma NSO and SP2/0 cell lines are those most commonly used [61], although differences have been found in the glycosylation of the antibodies produced. Hence, for example, these cells can add terminal galactoses with an $\alpha 1,3$ bond that is very immunogenic. That is why $\mathrm{CHO}$ and monkey cells are currently used, as they lose the enzyme responsible for the $\alpha 1,3$ galactosyl bond [62] .

5.3. Use of SCID/Trimera Mice. Another technique is based on the use of immunodeficient mice, such as Severe Combined Inmunodeficiency (SCID) mice, which have a severe combined immunodeficiency due to an autosomal recessive alteration of the enzyme responsible for the rearrangements of the antigen receptors of the B and T lymphocytes. Various research groups [63-65] showed that fetal haematopoietic tissues and mononuclear cells of human peripheral blood settled in this type of mouse.

Another approach is the development of Trimera mice, where the mice are submitted to total body irradiation followed by the transplantation of bone marrow from SCID mice for, subsequently, receiving human haematopoietic tissue. Both types of mice have been used for obtaining human monoclonal antibodies by introducing antigenspecific human lymphocyte cells, subsequent immunization of the mouse, and the production of hybridomas by the conventional technique [66]. However, keeping these mice is difficult and requires special equipment and specific sterile conditions, which are out of reach for many laboratories, as these mice tend to suffer from agammaglobulinemia, severe lymphocytopenia and frequent infections due to their immunodeficiency. In contrast, they are used for studying diseases or implanting tissues of other animal species, as the functioning of the monocytes, granulocytes and NK cells is normal.

5.4. Use of Chicken Eggs. The production of human monoclonal antibodies using chicken eggs has recently been described. The technique is based on the insertion of the coding genes of the human antibody into embryonic cells, and then introducing these cells into chicken embryos [67]. The antibodies produced have similar biological and physical characteristics as conventional antibodies. In addition, these antibodies lose their mucosal residue, increasing their antibody-dependent cytotoxicity versus other types of antibodies.

5.5. Use of Plants. Scientists from Jefferson Medical College, Philadelphia, USA and from the Cuban Centro para el Control Estatal de la Calidad de los Medicamentos (CECMED) (State Centre for Drug Quality Control) have successfully tested, in laboratory experiments, monoclonal antibodies obtained from transgenic tobacco plants, which recognize and destroy breast cancer cells and those of colon and rectal cancer.

Tobacco plants have been genetically transformed with the human antibody against the Lewis $\mathrm{Y}$ antigen, which is found in tumoral cells, making the plants factories for producing human antibodies. It has been shown that recombinant antibodies are at least as efficient as those of mammalian cell cultures obtained using conventional methods, with the advantages of having much lower production costs, permitting eventual mass production, and of being safer in regard to possible contamination.

Clinical trials of these antibodies will be carried out during the next $5-10$ years.

5.6. Use of Transgenic Mice for Human Immunoglobulins: The XenoMouse. Given the problems mentioned in obtaining completely human antibodies, another possibility proposed by scientists was the development of transgenic mice with sequences of producer genes of human immunoglobulins, which, therefore, were able to generate human-specific antibodies. In the 1990s, and thanks to the development of techniques in Molecular Biology, microinjection, and manipulation of embryonic cells, a race began among various research groups to produce genetically modified mice that could produce human antibodies. This type of mouse is known as XenoMouse and has human immunoglobulin transgenes containing a large part of the $\mathrm{V}$ gene repertoire in the terminal line, which supports the development of a large population of B lymphocytes and the formation of a broad and diverse primary immune repertoire, secreting human antibodies $[68,69]$. The human genes are compatible with the factors that mediate the rearrangement of the genes and with the mouse enzymes that mediate class switching, the introduction of mutations (somatic hypermutation) and affinity maturity [70].

The vectors that have been used by different authors for the introduction of human Igs in mice have essentially been miniloci, P1 vectors, and yeast artificial chromosomes (YACs) and, more recently, entire or almost entire chromosomes. While miniloci can incorporate a few $\mathrm{Kb}$ of DNA, the YAC vectors can include large segments of exogenous DNA (up to $1-2 \mathrm{Mb}$ ) and can be modified in a rapid and effective way using recombination processes. The fundamental advantages of using spheroblast fusion that contains YACs are that they do not require DNA purification processes, and that the methodology is similar to the standard processes of somatic fusion of mouse splenocytes for obtaining monoclonal antibodies. Using xenomouse secreting human antibodies our group has developed several human monoclonal antibodies directed against human leucocyte cells [71-75]. 


\section{Therapeutic Uses of Monoclonal Antibodies}

Currently, therapy with monoclonal antibodies is the largest growth area in the pharmaceutical industry. The development of Genetic Engineering and Immunology in recent years, with the subsequent production of all the types of antibodies described, is opening the door to hope for many therapies.

Numerous patients are already benefiting from the use of monoclonal antibodies as therapies against various diseases, and there are many more where the antibodies are still in different phases of clinical trials, prior to approval for commercial therapy.

Antitumoral therapy stands out among the treatments for diseases where monoclonal antibodies are currently being used. Some of the reasons that have driven the search for new therapeutic weapons are: the high incidence in the population of different types of cancer; the extremely severe nature of many of these cancers without adequate treatment; the resistance of the tumoral cells to many treatments; the absence of effective therapies; and the extreme toxicity of certain current treatments. Among this new armoury, monoclonal antibodies can offer a specific weapon that can be directed against the tumoral cell without affecting, or with only minimum effect, upon healthy tissues and with less adverse effects than other therapies.

Tumoral cells generally express antigens on the outer space, specific to their lineage, signalling proteins, growth receptors, and for B-cell proliferative syndromes, membrane immunoglobulins. Many of these antigens are identical to those expressed by precursor cells or non-tumoral adult cells. Therefore, to be good candidates as therapeutic targets, they have to be overexpressed in target cells or, in some cases, be specific to them. Hence, the success of the treatment with antibodies depends upon the ability of the cells to tolerate collateral damage or to be reconstituted by the negative precursor cells for the target antigen [76].

Monoclonal antibodies can be therapeutically useful through a variety of mechanisms, from the simple blocking of the antigen receptor in the effector cells, to cytotoxic action on the cells that express the corresponding antigen, with numerous intermediate options of cellular modulation.

\section{Monoclonal Antobodies Approved for Therapeutic Use by the FDA}

The Food and Drug Administration (FDA) of the United States has approved 26 monoclonal antibodies for clinical use, either therapeutic or diagnostic (Table 1), while around 150 are in different phases of clinical trials (http://www.fda.gov/). The situation is similar in the European Union, as since 1995 when the European Medicines Agency (EMEA) was set up, the registration process for this type of drug is a centralized European procedure, which coordinates the efforts for evaluation and control of these very particular medicines.

Most of the antibodies that have, so far, been approved are targeted against different tumoral processes and are humanized, chimeric and murine antibodies (Table 1). The list of monoclonal antibodies that are currently in different phases of clinical trials means that there will be an increase of around 100 monoclonal antibodies in 2010.

\section{Nanoparticles and Antibodies}

The antibody-conjugated nanoparticles can be used principally in two biomedical applications: therapy and diagnosis. In therapy, the development of targeted drug delivery represents, together with tissue repair, the main applications of antibody-conjugated nanoparticles. In diagnosis, the applications can be divided into those using in vivo and those using in vitro experimentation (Figure 4), and include contrast agents for magnetic resonance imaging (MRI), sensing, cell sorting, bioseparation, enzyme immobilization, immunoassays, transfection (gene delivery), purification, and so forth. The importance of all these applications can be demonstrated by a list of all the companies involved in the synthesis and applications of antibody conjugated nanoparticles (Table 2); for example, cell sorting and bioseparations are the main applications where a significant number of companies are currently commercializing their products.

\section{Therapeutic Applications of Antibody-Conjugated Nanoparticles}

Commercial antibodies are already on the market either attached to drugs (Mylortag ${ }^{\circledR}$ ) or to radioisotopes (i.e., ProstaScint $\left.{ }^{\circledR}\right)$, used in the treatment of acute myeloid leukaemia and prostate cancer, respectively. However, to date, there are no commercial antibodies conjugated to nanoparticles applied in therapy, although the combination of nanoparticles and antibodies can offer versatility together with specificity (Figure 5), and there is a huge potential market.

The combination of antibodies and nanoparticles has been developed at a stunning pace, as can be observed in Figure 6, where the number of articles (as indexed by ISI Web of Knowledge ${ }^{\circledR}$ ) published increased almost exponentially during the last years (2009 data were not yet definitive when the search was carried out (June19, 2009).

Reviewing those articles we can conclude that targeted drug and gene delivery together with magnetic or optical hyperthermia are the main potential therapeutic applications for antibody-conjugated nanoparticles. Each one is in a different development phase. All these applications have in common the selective delivery of a therapeutic carrier, such as a drug, a gene or heat, to cause the death of malignant cells, the expression of a specific protein or the activation of others, without affecting the surrounding healthy tissues.

Specific targeting is commonly achieved using passive or active strategies. Passive targeting employs the characteristic microvasculature of tumours to tailor the nanoparticles to be accumulated on these targets. The nanoparticles accumulate due to their specific size and their extravasation within the tumour, where the microvasculature is hyperpermeable and leaky, a process also aided by the tumour-limited lymphatic drainage. In combination, these factors lead to 
TABLE 1: Monoclonal antibodies approved for human therapy, their applications and data of approval by FDA and/or EMEA.

\begin{tabular}{|c|c|c|c|}
\hline Product & Company & Applications & Approval \\
\hline $\begin{array}{l}\text { Muromomab } \\
\text { (Orthoclone OKT3) }\end{array}$ & $\begin{array}{l}\text { Ortho Biotech, Inc. } \\
\text { (Johnson \& Johnson) }\end{array}$ & Mouse IgG2a anti-CD3. Transplantation Rejection & $\begin{array}{l}\text { FDA } 1986 \\
\text { EMEA } 1987\end{array}$ \\
\hline Abciximab (ReoPro) & Centocor B.V. & Chimeric 7E3 directed against platelet glycoprotein IIb/IIIa & FDA 1994 \\
\hline $\begin{array}{l}\text { Nofetumomab } \\
\text { (Verluma) }\end{array}$ & $\begin{array}{l}\text { Boehringer Ingelheim } \\
\text { Pharma KG }\end{array}$ & $\begin{array}{l}\text { Mouse Fab IgG } \mathrm{F}_{2 \mathrm{~b}} \text { directed against glycoprotein } 40 \mathrm{kD} \\
\text { (expressed in several tumours). Conjugated to Tecnecio }\end{array}$ & FDA 1996 \\
\hline $\begin{array}{l}\text { Imciromab-Pentetate } \\
\text { (Myoscint) }\end{array}$ & $\begin{array}{l}\text { Centocor (Johnson \& } \\
\text { Johson) }\end{array}$ & Mouse Fab-Indio ${ }^{111}$, directed against human heart miosin & FDA 1996 \\
\hline $\begin{array}{l}\text { Arcitumomab } \\
\text { (CEA-Scan) }\end{array}$ & Immunomedics Inc. & $\begin{array}{l}\text { Mouse Ig Fragment-Tecnecio }{ }^{99} . \text { Directed against } \\
\text { carcinoembrionic antigen }\end{array}$ & $\begin{array}{l}\text { FDA } 1996 \\
\text { EMEA 1996, } \\
\text { Retired } 2005\end{array}$ \\
\hline $\begin{array}{l}\text { Capromab Pendetide } \\
\text { ProstaScint }\end{array}$ & Cytogen Corp. & Mouse Ab-Indio ${ }^{111}$. Detection of prostate tumour & FDA 1996 \\
\hline $\begin{array}{l}\text { Daclizumab } \\
\text { (Zenapax) }\end{array}$ & $\begin{array}{l}\text { Hoffman-LA Roche } \\
\text { Inc. }\end{array}$ & Humanized $\operatorname{IgG}_{1}$ anti-IL- $2 \alpha$. To avoid transplant rejection & $\begin{array}{l}\text { FDA } 1997 \\
\text { EMEA } 1999\end{array}$ \\
\hline Rituximab (Rituxan) & Genentech Inc. & Chimeric Ig antiCD20 for Non-Hodgkin lymphomas & $\begin{array}{l}\text { FDA } 1997 \\
\text { EMEA } 1998\end{array}$ \\
\hline $\begin{array}{l}\text { Basiliximab } \\
\text { (Simulect) }\end{array}$ & $\begin{array}{l}\text { Novartis } \\
\text { Phamaceutical Corp. }\end{array}$ & Chimeric anti-IL-2 $\alpha(\mathrm{CD} 25)$. To avoid renal transplant & $\begin{array}{l}\text { FDA } 1998 \\
\text { EMEA } 1999\end{array}$ \\
\hline $\begin{array}{l}\text { Palivizaumab } \\
\text { (Sinagis) }\end{array}$ & Medimmune Inc. & Humanized $\operatorname{IgG}_{1}$; respiratory syncitial virus & $\begin{array}{l}\text { FDA } 1998 \\
\text { EMEA } 1999\end{array}$ \\
\hline $\begin{array}{l}\text { Trastuzumab } \\
\text { (Herceptin }^{\circledR} \text { ) }\end{array}$ & Genentech Inc. & Humanized IgG anti-HER2; breast cancer & $\begin{array}{l}\text { FDA } 1998 \\
\text { EMEA } 2000\end{array}$ \\
\hline $\begin{array}{l}\text { Remicade } \\
\text { (Infliximab) }\end{array}$ & $\begin{array}{l}\text { Centocor (Johnson \& } \\
\text { Johnson) }\end{array}$ & Chimeric anti TNF- $\alpha$. Rheumatoid arthritis, Crohn's disease & $\begin{array}{l}\text { FDA } 1998 \\
\text { EMEA } 2002\end{array}$ \\
\hline $\begin{array}{l}\text { Gemtuzumab } \\
\text { Ozogamicin } \\
\text { (Mylotarg) }\end{array}$ & Wyeth Averst & Humanized Ig anti CD33; acute myeloid leukaemia & FDA 2000 \\
\hline $\begin{array}{l}\text { Alemtuzumab } \\
\text { (Campath) }\end{array}$ & $\begin{array}{l}\text { Millennium/ Ilex } \\
\text { Partners LP }\end{array}$ & Humanized Ig anti CD52; chronic lymphocitic leukaemia & $\begin{array}{l}\text { FDA } 2001 \\
\text { EMEA } 2001\end{array}$ \\
\hline $\begin{array}{l}\text { Adalimumab } \\
\text { (Humira) }\end{array}$ & Abbott Laboratories & Human anti TNF- $\alpha$. Rheumatoid arthritis & $\begin{array}{l}\text { FDA } 2002 \\
\text { EMEA } 2003\end{array}$ \\
\hline $\begin{array}{l}\text { Ibritumomab } \\
\text { Tiuxetan (Zevalin) }\end{array}$ & $\begin{array}{l}\text { IDEC } \\
\text { Pharmaceuticals } \\
\text { Corp. }\end{array}$ & Mouse Ig-Itrio 90 anti CD20. Non-Hodgkin lymphoma & $\begin{array}{l}\text { FDA } 2002 \\
\text { EMEA } 2004\end{array}$ \\
\hline Omalizumab (Xolair) & Genentech Inc./Roche & Humanized IgE. Severe asthma & $\begin{array}{l}\text { FDA } 2003 \\
\text { EMEA } 2005\end{array}$ \\
\hline $\begin{array}{l}\text { Tositumomab } \\
\text { (Bexxar) }\end{array}$ & GlaxoSmithKline & Murine Ig-Iodo ${ }^{131}$ anti CD20. Non-Hodgkin lymphoma & FDA 2003 \\
\hline Efalizumab (Raptiva) & Genentech Inc./Roche & Humanized Ig anti-CD11a & FDA 2003 \\
\hline Cetuximab (Erbitux) & $\begin{array}{l}\text { ImClone Systems/ } \\
\text { Bristol-Nyers } \\
\text { Squibb/Merck KgaA }\end{array}$ & $\mathrm{IgG}_{1}$ directed against EGFR; colorectal tumour & FDA 2004 \\
\hline $\begin{array}{l}\text { Bevacizumab } \\
\text { (Avastin) }\end{array}$ & Genentech Inc. & Humanized anti VEG; tumours & $\begin{array}{l}\text { FDA } 2004 \\
\text { EMEA } 2005\end{array}$ \\
\hline $\begin{array}{l}\text { Natalizumab } \\
\text { (Tysabri) }\end{array}$ & Biogen Idec & Humanized anti CD49d. Multiple Sclerosis, Chron's disease & $\begin{array}{l}\text { FDA } 2006 \\
\text { EMEA } 2006\end{array}$ \\
\hline $\begin{array}{l}\text { Panibizumab } \\
\text { (Lucentis) }\end{array}$ & Genentech Inc. & Humanized anti VEGF-A. Wet Macular Degeneration & $\begin{array}{l}\text { FDA } 2006 \\
\text { EMEA } 2007\end{array}$ \\
\hline $\begin{array}{l}\text { Panimumab } \\
\text { (Vectibix) }\end{array}$ & Amgen & $\begin{array}{l}\text { Human anti EGFR (epidermal growth factor receptor). } \\
\text { Metastatic colorectal carcinoma }\end{array}$ & FDA 2006 \\
\hline
\end{tabular}


Table 1: Continued.

\begin{tabular}{llll}
\hline Product & Company & Applications & Approval \\
\hline $\begin{array}{l}\text { Eculizumab (Soliris) } \\
\text { Certolizumab Pegol }\end{array}$ & $\begin{array}{l}\text { Alexion } \\
\text { Pharmaceuticals Inc. }\end{array}$ & $\begin{array}{l}\text { Humanized anti CD59. Paroxysmmal nocturnal } \\
\text { hemoglobinuria }\end{array}$ & FDA 2007 \\
$\begin{array}{l}\text { Eimzia) } \\
\begin{array}{l}\text { Golimumab } \\
\text { (Simponi) }\end{array}\end{array}$ & $\begin{array}{l}\text { Humanized Fab anti-TNF- } \alpha \text {. Morbus Chron, rheumatoid } \\
\text { arthritis }\end{array}$ & FDA 2008 \\
\hline
\end{tabular}

TABLE 2: Companies involved in the synthesis and applications of antibody conjugated micro and nanoparticles.

\begin{tabular}{|c|c|c|}
\hline Company & Applications & Website \\
\hline Ademtech SA & Cell sorting, Biomagnetic Separation & http://www.ademtech.com/ \\
\hline Alnis Biosciences Inc. & $\begin{array}{l}\text { Under development: } \\
\text { antibody-conjugated magnetic } \\
\text { nanoparticles for diagnosis and treatment }\end{array}$ & http://www.alnis.com/ \\
\hline Bangs Laboratories Inc. & $\begin{array}{l}\text { Biomagnetic separation of cells, } \\
\text { organelles, proteins, immunoglobulins, } \\
\text { nucleic acids, and so forth. }\end{array}$ & http://www.bangslabs.com/ \\
\hline Chemicell & Binding of secondary antibody & http://www.chemicell.com/ \\
\hline Diagnostic Biosensors, LLC & Immunoassays, biosensors & http://www.diagnosticbiosensors.com/ \\
\hline Indicia Biotechnology S.A. & Biomagnetic separation & http://www.indicia.fr/ \\
\hline Invitrogen Corp. & $\begin{array}{l}\text { Immunoassay, cell separation, binding of } \\
\text { secondary antibody }\end{array}$ & http://www.invitrogen.com/ \\
\hline LifeAssays ${ }^{\circledR}$ & Magnetic biosensors & http://www.lifeassays.com/ \\
\hline Magnamedics GmbH & Biomagnetic separation & http://www.magnamedics.com/ \\
\hline Magnisense SAS & Immunoassays, biosensors & http://www.magnisense.com/ \\
\hline MagSense Life Sciences, Inc. & Biomagnetic separation & http://www.magsenselifesci.com/ \\
\hline Merck \& Co., Inc. (Estapor ${ }^{\circledR}$ ) & $\begin{array}{l}\text { Magnetic bioseparation or } \\
\text { biopurification of antigens, antibodies or } \\
\text { nucleic acids }\end{array}$ & http://www.estapor.com/ \\
\hline Micromod Partikeltechnologie GmbH & Biomagnetic separation & http://www.micromod.de/ \\
\hline Miltenyi Biotec GmbH & $\begin{array}{l}\text { Biomagnetic separation of cells, indirect } \\
\text { magnetic labelling, isolation of apoptotic } \\
\text { and dead cells }\end{array}$ & http://www.miltenyibiotec.com/ \\
\hline Nanosphere, Inc. & Optical biosensors & http://www.nanosphere.us/ \\
\hline Spherotech Inc. & Biomagnetic separation & http://www.spherotech.com/ \\
\hline Stemcell Technologies & Biomagnetic and no-magnetic separation & http://www.stemcell.com/ \\
\hline Triton Biosystems Inc. & $\begin{array}{l}\text { Under development or in pre-clinical } \\
\text { development: targeted nanoparticles for } \\
\text { hyperthermia }\end{array}$ & http://www.tritonbiosystems.com/ \\
\hline
\end{tabular}

the selective accumulation of nanoparticles of sizes generally between 80 and $200 \mathrm{~nm}$ in tumour tissue, a phenomenon known as enhanced permeation and retention (EPR). In general, the smaller the nanoparticle, the longer is its circulation time. Although vasculature organization may differ depending on the tumour type, its growth rate and, microenvironment, most solid tumours exhibit a vascular pore cut-off size between 380 and $780 \mathrm{~nm}$ [77]. Particles that are too small $(<80 \mathrm{~nm})$ may be cleared very quickly from the tumour vasculature by drainage through the capillary pores. Therefore, there is an optimum size for the nanoparticles to be accumulated in the proximity of a tumour. Usually, passive targeting is applied by injecting the nanoparticles near the artery that feeds the tumour, and produces good results in terms of reducing the tumour size.

Active targeting is based on the over- or exclusiveexpression of different epitopes or receptors in the tumoral cells, and on specific physical characteristics. In addition to all the moieties mentioned in the introduction, antibodies represent one of the most interesting bioconjugates used to achieve the active targeted delivery of a therapeutic carrier. Moreover, active targeting is successful using the physical properties of the nanoparticles (i.e., magnetism) [78]. The combination of different active targeting strategies, both the physical and those aided by specific recognition moieties, is also possible. 


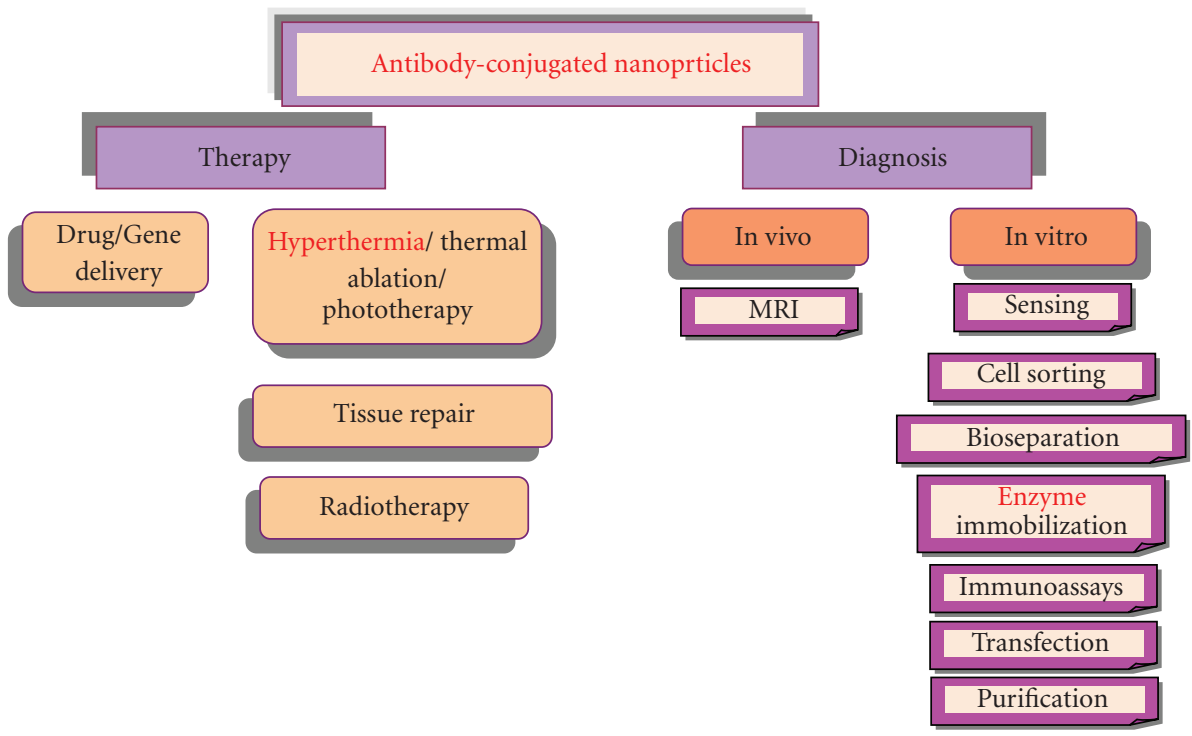

FIGURE 4: General scheme of the different applications for antibody conjugated nanoparticles.

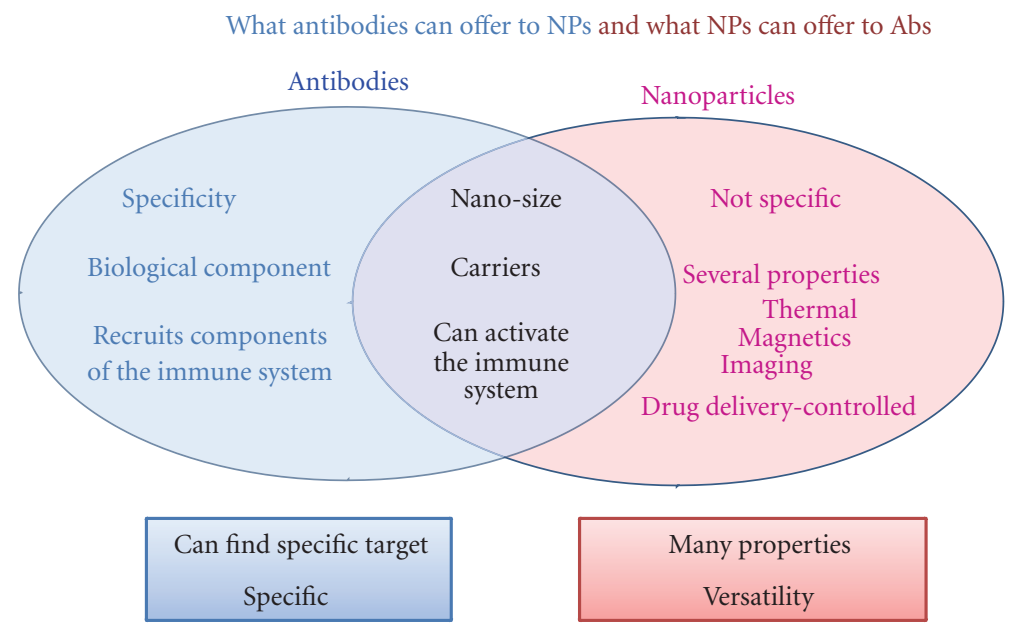

FIgURe 5: Advantages in the conjugation of nanoparticles to antibodies.

9.1. Targeted Drug Delivery. Antibody-conjugated drugloaded nanoparticles can selectively target malignant cells and release large amounts of a drug in the cell cytoplasm, minimizing undesired side effects. The efficacy of the delivery depends on the ability of each antibody to reach its target in adequate quantities, and on the limited amount of nanoparticles trapped by the cell. Since the early studies in 1977 of antifolates linked to cytotoxic drugs (methotrexate) demonstrated therapeutic action in mice [79], the idea of conjugating a drug-loaded nanoparticle to an antibody for the targeted recognition of malignant tissue has opened the development of new targeted nanocarriers. The need to use nanocapsules (with a hollow interior filled with the drug) depends upon the amount of drug required to cause cellular death. For example, on the cell line MCF-7 it has been shown that for $50 \%$ cell killing $10^{7}$ molecules of a drug (daunomycin) have to be present per cell [80]. Given that the number of antigens recognised by tumour-associated antibodies on cell surfaces is reported to be in the range $10^{5}-10^{7}$ per cell, it would be difficult to deliver a sufficient amount of even the most potent conventional cytotoxic agent through specific antibody delivery systems, solely with antibodies [81]. Moreover, there appears to be an upper limit for antigen-antibody binding affinity. Beyond this limit, further improvements in affinity have no beneficial effects [82].

The following are some examples of antibody-conjugated nanoparticles used in targeted drug delivery.

(i) Gupta and Torchilin (2007) described the synthesis and efficacy of the monoclonal anticancer antibody 2C5 conjugated to commercially available PEGylated liposomes loaded with doxorubicin (a DNAinteracting drug widely used in chemotherapy), in 


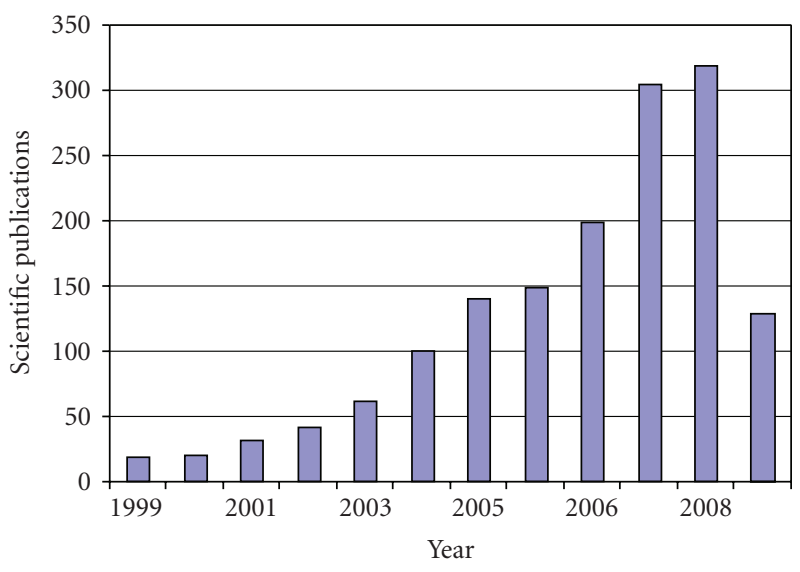

(a)

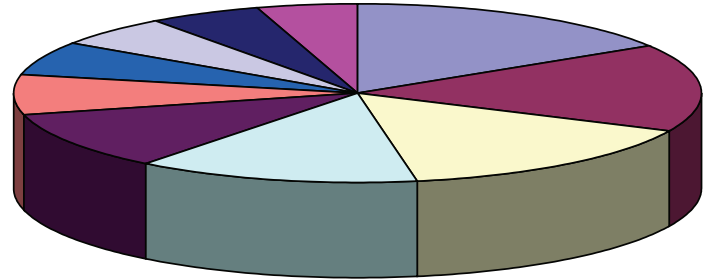

Biochemistry \& molecular biology

Science \& technology-other topics

$\square$ Chemistry

$\square$ Immunology

$\square$ Pharamacology \& pharamcy

$\square$ Instruments \& instrumentation

$\square$ Engineering

$\square$ Cell biology

Physics

(b)

Figure 6: (a) Number of papers related to antibodies and nanoparticles published in each year in the 1999-2009 period of time. Topic $=$ (antibodies and nanoparticles). ${ }^{*}$ Note: 2009 is uncompleted (search done on 19/06/2009). (b) Ranking of the scientific publications by subject area.

an intracranial model in nude mice [83]. The treatment with the antibody-conjugated liposomes provided a significant therapeutic benefit over controls, with a pronounced reduction in the tumour size.

(ii) Poly(d,l-lactide-co-glycolide)/montmorillonite nanoparticles (PLGA/MMT NPs) have been decorated with human epidermal growth factor receptor-2 (HER2) antibody, Trastuzumab (Herceptin ${ }^{\circledR}$ ), for targeted breast cancer chemotherapy with paclitaxel as a model anticancer drug [84]. According to the authors, their in vitro studies revealed that the therapeutic effects of the drug formulated in the conjugated nanoparticles could be 12.7 times higher than that of the bare nanoparticles, and 13.1 times higher than $\operatorname{Taxol}^{\circledR}$. The same humanised IgG1 monoclonal antibody has been covalently attached to human serum albumin-based nanoparticles, and the resulting carrier showed specific targeting to HER2positive breast cancer cells [85].

(iii) Paclitaxel-loaded poly(lactide-co-glycolide) (PLGA) nanoparticles coated with cationic SM5-1 singlechain antibody $(\mathrm{scFv})$, containing a polylysine (SMFv-polylys), were synthesized and effectively tested in vitro. The purpose of tagging the antibody with the cationic polypeptide polylysine is to achieve electrostatic attraction with the negatively charged nanoparticles [86]. When compared to nontargeted paclitaxel-loaded PLGA nanoparticles, the antibodyconjugated nanoparticles showed enhanced in vitro cytotoxicity against human hepatocellular carcinoma cell lines (Ch-hep-3).

(iv) Two different monoclonal antibodies have been covalently coupled to the same poly-(malic acid)-based nanoparticle, one of them, monoclonal anti-TfR, to direct the conjugate across the blood-tumour barrier, and the other, monoclonal $2 \mathrm{C} 5$, to target tumourcell surface-bound nucleosomes. The presence of both antibodies on the same nanoparticle and their biological activity were confirmed by ELISA. In vivo experiments showed the significantly higher accumulation of the conjugated nanoparticles in human glioma [87].

(v) Tyner et al. [88] have recently reported the surface functionalization of inorganic nanoparticles (made of magnesium-aluminium layered double hydroxides) with disuccinimidyl carbonate (DSC), which were then loaded with a huA33 antibody and a blood plasma protein (serum albumin). The biological in vitro tests showed that LDH-DSC-huA33 nanobiohybrids had an activity against human A33 antigen 30 times higher than that of LDH-DSC-albumin.

9.2. Gene Delivery and Tissue Repair. Excluding rare exceptions, bare DNA does not internalize the cells nor does it express a specific protein at a reasonable level. The carriers that help the DNA to internalize into the cell can be administered systemically or locally (by direct injection in the tissue or by using DNA-loaded scaffolds). Viral carriers, cationic lipids and polymers, recombinant proteins, and inorganic nanoparticles are the four kinds of carriers used. Some of these vectors may be functionalized with antibodies or Fabs for targeting cell delivery, while others, with short peptide sequences, act as nuclear localisation signals.

Nanoparticles have been used as carriers of plasmid DNA, oligonucleotides, siRNA, and so forth, to transfect cells and use the cellular machinery to produce therapeutic proteins, to activate a cellular response or to differentiate 
the cells into specific ones. The nanoparticle can behave as a protective coating to the moiety. For instance, synthetic siRNAs are a very promising new tool for therapeutic intervention; however, it is necessary to improve their cellular target specificity, their effective cellular delivery (particular into primary cells), as well as their stability [89].

Hayes et al. [90] described the use of an antibodylipopolymer (anti-HER2 scFv (F5)-PEG-DSPE) conjugated to a cationic lipid nanoparticle with the DNA encapsulated in its interior, which achieves a high degree of specific transfection activity.

Several research groups, interested in the noted blood instability of siRNA, have been working on their chemical modification and on their encapsulation for protection against degradation in transfection applications. One group, Heidel et al. (2007) [91], described the use of transferrin protein as a targeting ligand conjugated to cyclodextrinebased nanoparticles, which encapsulate siRNA for inhibiting gene expression in nonhuman primates. Most of these gene delivery carriers have applications in regenerative medicine.

Bare and antibody-conjugated gold nanoparticles that absorb light in the near infrared have been shown to be optically-absorbing nanoparticles for enhanced tissue repair [92]. The heat adsorbing properties of gold nanocolloids are used in this case to produce tissue welding.

9.3. Magnetic Hyperthermia, Thermal Ablation, and Photodynamic Therapy. Anticarcinoembryogenic antibodies of human LoVo cancer cells have been attached to $\mathrm{TiO}_{2}$ nanoparticles [93]. The electrons in the valence band of $\mathrm{TiO}_{2}$ nanoparticles can be excited, under UV light irradiation, to the conduction band, creating pairs of photo-induced electrons and holes. These photo-induced electrons and holes present strong reduction and oxidation properties, which can destroy malignant cells, due to the generation of reactive oxygen species under ultraviolet irradiation. The antibodies were labelled with FITC for improving optical detection by using confocal laser microscopy [94]. Electroporation (use of electric stimulation to deliver moieties through the micropores on the cell membrane) was used to accelerate the internalization of the conjugated nanoparticles into cancer cells. In vitro results showed that $100 \%$ of human cancer cells were photokilled within $90 \mathrm{~min}$ using the combination of both techniques.

For the same application, polyacrylic acid-coated $\mathrm{TiO}_{2}$ nanoparticles were covalently coupled to antiestradiol mouse antibodies with an amide bond, and used not only in the recognition of the estradiol, but also in its destruction by using the previously mentioned photocatalytic properties of $\mathrm{TiO}_{2}$. There are clear applications for these carriers in environmental protection for water treatment technology, as well as in medical and public sanitation waste-treatment processes [95].

El Sayed et al. [96] showed selective laser photothermal destruction of two oral squamous carcinoma cell lines (HSC 313 and HOC 3 clone 8), versus a benign epithelial cell line (HaCaT), by using anti-EGFR antibody conjugated to pure gold nanoparticles. Gold nanoparticles show heat-adsorbing properties under near infrared radiation (NIR), whereas tissue does not adsorb NIR light.

Staphyloccocus aureus bacteria were killed by lightadsorbing gold nanoparticles conjugated to anti-protein A antibodies, using laser irradiation at $532 \mathrm{~nm}$ [97]. Protein A was chosen because it interacts specifically with the Fc fragment of the antibody. According to the authors, killing efficiency depends on the local overheating effects accompanied by bubble-formation phenomena. Direct irradiation of bacteria with the laser did not damage the bacteria, because of low absorption by natural endogenous cytochromes.

Gold-coated silica nanoparticles have been used in phototherapy in the near infrared [98] showing a potential application in tumours present on the external surface of the body. The in vitro results showed an irreversible thermal damage for human breast carcinoma cells incubated with the nanoparticles after exposure to NIR light, whereas control tissues appeared to be undamaged.

Pharmacokinetics, tumour uptake, and the therapeutic effect of inductive heating (by externally applying alternating magnetic fields, AMF) of ${ }^{111}$ In-chimeric L6 (ChL6) monoclonal antibody-linked iron oxide nanoparticles were studied in athymic mice bearing human breast cancer HBT 3477 xenografts. Tumour regression was observed at all AMF levels after those carriers were delivered to the cancer cells [99]. In magnetic hyperthermia, heat is produced by increasing the alternating magnetic field amplitude and/or field frequency, due to the high specific absorption rate of magnetic nanoparticles.

The main disadvantage of magnetic hyperthermia is that there is a limitation in the external field strength that can be applied to create an adequate gradient to target the magnetic nanoparticles in the desired area. The magnetic gradient decreases rapidly with increased distance from the external magnet. The same spatial limitation would occur for phototherapy using NIR.

9.4. Encapsulation of Biomolecules for Bioanalytical, Therapeutic, and Environmental Purposes. Monoclonal antibodies may have low physico-chemical stability and short in vivo half-life. Their encapsulation or conjugation to nanoparticles may offer an alternative to avoid those problems. Nanoparticles can also encapsulate a drug or protect it within the pores of their structure, offering potential protection from metabolism, enzymatic degradation, and filtration. In addition, the use of nanoparticles to encapsulate the drug has the clear advantages that the drug activity is not affected by coupling reactions, and that they have an inherent high drugloading capacity.

The main application of encapsulated antibodies within nanoparticles relies on their use as biosensors. Antibodies are used for analytical purposes in immunoassays, selective analyte enrichment (immunoaffinity extraction), and in biosensors. In one study, anti-diclofenac antibodies were encapsulated within porous silica nanoparticles prepared by the sol-gel method [100]. The capsule provides the antibody with protection without loss of biological activity. The same authors show several antibodies encapsulated in different matrices. 
Special mention should be given to the use of nanoparticles to encapsulate antigens for vaccination purposes. The capsule provides the antigen with enhanced solubility and circulation time in the blood stream and, in some cases, immunostimulation [101]. Nanoparticles may present targeting ligands and sequestrate and release guest molecules [102]. The ability to induce potent and specific HIV1 humoral and cellular immune responses in vivo has been demonstrated for antigen-loaded poly $(\gamma$-glutamic acid $)$ nanoparticles [103]. Cationic nanoparticles have been used as a nasal delivery system for two recombinant proteins (HBsAg and $\beta$-galactosidase), which require humoral, cellular and mucosal responses in vivo [104]. N-trymethyl chitosan nanoparticles loaded with influenza subunit antigen have been shown to be effective carriers for the enhanced response of systemic and local immune response in mice [105]. In this case, the local uptake is mainly based on the mucoadhesive properties of the nanoparticles, due to their electrostatic attraction to the negatively charged nasal mucosa.

Simultaneous surface coating of two vaccine antigens (HIV-1 p24 and gp120 proteins) on poly(lactic-co-glycolic acid) or polylactic acid nanoparticles by adsorption was used to prove their immunogenicity in mice as well as their stability, assessed by a specific antibody binding assay [106].

Single-chain $\mathrm{Fv}$ antibodies that specifically bind and enter prostate cancer cells have been loaded within liposomes. The liposomes possess a $\mathrm{pH}$-sensitive fluorophore that allows the quantification of the conjugated liposomes uptake within the endosomal compartment [107].

\section{Antibody-Conjugated Nanoparticles in Diagnosis}

10.1. Cell Sorting. Without doubt cell sorting and bioseparation are the main applications for the antibody-conjugated nanoparticles. As can be seen in Table 1, several companies offer equipment for cell bioseparation.

In 1981, Kandzia et al. [108] described the use of a monoclonal HLA-BW6 antibody coupled to albumincoated magnetite microspheres via surface-incorporated Staphylococcus aureus Protein-A. The mixture of HLABW6 and -BW4 human peripheral blood lymphocytes was incubated with these immunomicropheres and applied to a glass column located in a magnetic field. Only HLA-BW4 lymphocytes passed through the column and were collected. The recovered cells were $97 \%$ viable. Protein A (protein isolated from the cell wall of Staphyloccocus aureus) was chosen, because it interacts specifically with the Fc fragment of the antibody.

However, in vivo experiments provided evidence of competitive displacement of the same adsorbed antibody by serum proteins, and the nanoparticles were cleared up to the liver and spleen [109].

Coupling of a murine monoclonal antibody, HEA125, specific for human epithelial cells, to magnetic beads (from $50 \mathrm{~nm}$ to a few microns) permits the positive selection of a population containing essentially only tumour cells [110].
The problem with all cell types is that surface markers are represented on most, if not all, of the cells. Therefore, antibody-based magnetic separation is a powerful technique for obtaining pure cell populations, but not all the cells of the cell population [111].

10.2. Imaging. The diagnosis of cancer at early stages of growth is a critical factor for obtaining optimal results in therapy and for improving the chances of survival. There are several imaging techniques that help physicians in their diagnosis, including magnetic resonance imaging (MRI), positron emission tomography (PET), computed tomography (CT), ultrasound, radiography, photoacoustic imaging, fluoroscopy, and so forth. In some of these techniques antibody-conjugated nanoparticles may offer increased selectivity and sensitivity.

10.2.1. Radio-Conjugated Antibody-Functionalized Nanoparticles. As early as 1981, Mach et al. [112] published the first clinical results with 125I labelled anti-CEA monoclonal antibodies, describing the potential applications of those carriers. Nowadays, these vectors have been combined with nanoparticles, thereby, providing new enhanced properties.

The work of Natarajan et al. [113] describes the conjugation of commercial PEG-coated dextran-magnetic nanoparticles with isotopically labelled recombinantly generated antibody fragments, di-scFv-c, for the imaging and therapy (by applying magnetic hyperthermia) of anti-MUC1-expressing tumours. A chelator (DOTA) is linked to the antibody fragment in the first step. Subsequently, the conjugated antibody is incubated with a ${ }^{111}$ In precursor (isotopically labelled indium chloride) hybrid nanoparticle, and finally, this radiolabelled antibody fragment is linked to the previously described maleimide-functionalized magnetic nanoparticle, by a covalent attachment to a free cysteine of the fragment. The radiochelator is used to trace the nanoparticles in vivo.

10.2.2. Targeted Contrast Agents for MRI. Among clinical devices used for cancer diagnosis, Magnetic Resonance Imaging (MRI) stands out as a powerful tool, often superior to other technologies. MRI is a noninvasive and nondestructive powerful imaging modality, which provides internal images of living organisms with no limits in the depth of analysis, and with a resolution of $10-100 \mu \mathrm{m}$. It is versatile, as a wide range of MRI modalities can be accessed, and $2 \mathrm{D}$ and $3 \mathrm{D}$ imaging can be carried out [114].

MRI sensitivity can be improved by the use of contrast agents (approximately $30 \%$ of all the clinical MR are assisted by their use), which are active substances loaded with metal ions usually as nanoparticulates. The inclusion of magnetic nanoparticles as contrast agents for MRI prompted the design of new targeted contrast agents. In 1998, monoclonal antibodies directed against epidermal growth factor receptors (EGFRs), which are overexpressed in oesophageal squamous cell carcinoma, were covalently linked to superparamagnetic nanoparticles, showing enhanced contrast for tumour-specific MRI in a rat model bearing oesophageal squamous cell carcinomas [115]. 
Isolated rat islets have been cultivated with immunomagnetic beads coated with antibody against rat MHC class I antigen. Labelled islets were transplanted into the livers of syngeneic rats providing islet images in vivo [116].

The detection of fibrin in vitro by $\mathrm{MR}$ in unstable atherosclerotic plaques is possible by using paramagnetic nanoparticles conjugated to an antifibrin antibody (1H10) [117].

However, as mentioned above, the required dose of the labelled antibody is still too high to make commercial development realistic. Although biotechnology has advanced tremendously, the low expression of antigens or receptors and the limited sensitivity of the currently available relaxation enhancers are just some of the factors that call into question the potential of antibodies or their fragments for clinical MRI [118].

10.3. Sensing. Highly sensitive detection and accurate analysis of biomarker molecules in human fluid samples are essential for the early detection, treatment, and management of diseases [119].

In a biosensor, a ligand and a receptor bind together in a reaction that is collected as a signal to a transductor using different methods, including optical, magnetic, electrochemical, radioactive, piezoelectric, mechanical, mass spectrometric, and so forth. Like any sensor, a biosensor should be cheap, compact, selective, sensitive, portable, reusable, and have a fast readout.

The introduction of nanoparticles in the molecular diagnosis field has represented an advantage in many cases to well-established detection techniques based on fluorophores, such as Polymerase Chain Reaction (PCR) and EnzymeLinked ImmunoSorbent Assay (ELISA). Nanoparticles offer their physical properties to the biosensor. In some cases, nanoparticles are used simply as carriers of antibodies to recognize them by association in biosensors. For example, in 1996, surface plasmon resonance (SPR) was used, through the BIACORE ${ }^{\circledR}$ biosensor, to demonstrate the specific interaction between an anti-CD4 monoclonal antibody (IOT4a), adsorbed on poly(methylidene malonate 2.1.2) nanoparticles, and the CD4 molecule [120]. As can be seen in Table 1, several companies offer equipment based on antibody conjugated nanoparticles for biosensing applications.

10.3.1. Optical Sensors. The enhancement of optical immunosensors with nanoparticles was postulated as long ago as 1997 by Kubitschko et al. [121] Subsequently, many applications have demonstrated the superior capabilities of nanoparticles.

Noble metal nanoparticles exhibit a strong UV-visible absorption band that is not present in their bulk counterparts. For those nanoparticles localized, surface plasmon resonance excitation results in wavelength selective absorption; large molar extinction coefficients (superior to fluorophores); and enhanced local electromagnetic fields on the surface, responsible for intense signals in spectroscopy [122].

Magnetic nanoparticles labelled with the near-infrared fluorochrome Cy5.5 have been covalently bonded to anti
VCAM-1 antibodies by using EDC/Sulfo-NHS chemistry. An effective delivery and labelling of activated endothelium was demonstrated in vivo using a murine inflammatory model [123]. The fluorescent probe was used to provide fluorescence confocal images of the m-TNF activated endothelium in an ear model, and the magnetic part of the nanoparticles was used to provide magnetic resonance (MR) contrast for deep tissue imaging.

Gold nanoparticles are widely used in optical sensing, due to their large light absorption and scattering crosssection in the surface plasmon resonance wavelength region.

The magnitude of light scattering by gold nanoparticles can be orders of magnitude higher than light emission from strongly fluorescing dyes [119]. They do not photobleach and can be easily detected in as low as $10^{-16} \mathrm{M}$ concentration [124].

In addition, gold nanoparticles have been used as contrast agents for biomedical imaging using scanning optical microscopy [125], multiphoton plasmon-resonance microscopy [126], optical coherence microscopy and thirdharmonic microscopy [127]. Hirsch et al. [128] described the use of antibodies conjugated to gold nanoparticles to detect proteins in saline, serum, and whole blood by using near infrared spectroscopy with a sensibility of up to subnanograms $/ \mathrm{mL}$.

Gold-coated silver nanoparticles, covalently attached to goat anti-mouse IgG antibodies and to a reporter, were used in biosensing applications by employing surface enhanced Raman spectroscopy (SER) [129]. A capture antibody was immobilized on a substrate and a positive detection was observed when the goat IgG was present in the media.

Fluorescent reporter proteins embedded in polyacrylamide nanoparticles have been used for the sensing of inorganic phosphate, by using the fluorescence resonance energy transfer (FRET). The determination of inorganic phosphate is necessary to elucidate metabolic processes [130].

Anti-HER2 and anti-IgG gold-coated silica nanoparticle conjugates have been used to measure the number of targeted plasmonic nanoparticles that bind per cell, due to their strong light scattering properties. The ability to quantify this is crucial for improved diagnostic and therapeutic results. The polarized angular-dependent light scattering of the nanoparticles was studied using an automated goniometer, because of the linear relationship between the light scattering and the nanoparticle concentration [131].

Anti-prostate specific antibodies have been conjugated to gold nanoparticles and used to quantify the amount of prostate specific antigen (an FDA-approved biomarker for prostate cancer diagnosis) by utilizing dynamic light scattering. Even with a small level of nanoparticle instability and aggregation, a quantitative immunoassay is possible in a protein matrix solution, by using dynamic light scattering [119].

The scattering images and the absorption spectra recorded from anti-EGFR conjugated gold nanoparticles, incubated with cancerous (HOC 313 clone 8 and HSC 3 oral epithelial cell lines) and noncancerous cells (nonmalignant 
epithelial cell line $\mathrm{HaCaT}$ ), are very different, and offer potential techniques for cancer diagnosis [132].

The localized surface plasmon resonance absorbance in the visible region has been used as an optical method for the enhanced detection on an immunochromatographic test strip, by using monoclonal anti-human gonadotropin hormone (HCG) antibodies and monoclonal anti-human total prostate specific antigen antibodies (anti-TPSA), conjugated to gold nanoparticles. The conjugation took place by physical adsorption. The results showed a detection limit of HCG at $1-0.1 \mathrm{ng} / \mathrm{mL}$ with the naked eye, and a limit of $0.001 \mathrm{ng} / \mathrm{mL}(1 \mathrm{pg} / \mathrm{mL})$ with the concentration phenomena of the gold nanoparticles, using surface plasmon resonance measurements. TPSA was measured with a limit of detection of $0.2 \mathrm{ng} / \mathrm{mL}$ [133]. The pregnancy hormone was also determined, using magnetic nanoparticles conjugated to anti-HCG antibodies with covalent coupling [134].

Monoclonal mouse glycosylated antibodies have been conjugated through the Fc region to gold nanoparticles [135] and employed to produce nanoparticle labelling, using dark field transmittance imaging. Those contrast agents were validated in live NIH3T3 fibroblasts.

10.3.2. Mass Sensors. The most widely used mass biosensors are quartz crystal microbalances (QCMs) and cantilevers. In the former, a variation in the frequency of the resonance is directly correlated to the mass deposited on its surface (Sauerbrey equation). The QCM system is based on the principle that the resonant frequency shifts of piezoelectric crystal are directly proportional to the adsorbed molecular mass [136].

For liquid detection, a thin film of the analyte on the surface of the QCM is necessary for its accurate quantification. This adsorbed film may consist of a considerably large amount of water, which is sensed as a mass uptake by all QCMs. The measuring of several frequencies and the dissipation (the dissipation, or damping, is the sum of all energy losses in the system per oscillation cycle) makes it possible to determine whether the adsorbed film is rigid or water-rich (soft), which is not possible by only looking at the frequency response. Therefore, the evaluation of the dissipation is necessary in mass-based biosensing applications, and it is possible to evaluate the variation of the resonance frequency, after the deposition of a moiety, and/or also the deflection of the cantilever after the deposition. The damping problem also affects the cantilevers, but currently commercial applications include a corrector (named feedback) to subtract that contribution.

Piezoelectric QCMs have been used for direct detection of anti-Toxoplasma gondii immunoglobulins. For patients with weakened immune systems (including those with AIDS, cancer, or other chronic illnesses), toxoplasmosis can be fatal. Gold nanoparticles functionalized with Toxoplasma gondii antibodies were incubated with infected rabbit serum and blood. The nanoparticles are used to enhance the sensibility of the mass sensor, based on the specific agglutination of the antigen-coated gold nanoparticles on the QCM surface [137].
The same transductors have been used for the piezoelectric immunoassay of carbohydrate antigen CA19-9 (an important carbohydrate tumour marker expressed in several kinds of carcinomas), by utilizing hybrid nanoparticles composed of poly-L-lysine/hydroxiapatite and carbon nanotubes conjugated to mouse anti-CA19-9 antibodies [138]. The nanocomposite acts as a scaffold for protein immobilization.

QCMs have been used for the selective detection in serum of the marker protein $\mathrm{S} 100 \beta \beta$, which has been proposed to help distinguish between ischemic and hemorrhagic stroke [139]. A primary antibody was covalently attached to the treated surface of the QCM and, in the presence of the antigen, a streptavidin-coated magnetic nanoparticle functionalizated with a secondary antibody was sandwiched, enhancing the signal. The marker was measured in a concentration as low as $0.2 \mathrm{ng} / \mathrm{mL}$.

The surface of a QCM has been modified with a layer of gold nanoparticles and protein $\mathrm{A}$ to achieve an oriented attachment of antibodies (anti-CD3-FITC, antiCD5-FITC, anti-CD7-FITC, and mouse anti-human IgG1FITC) that recognize differentiated antigens of phenotypic lineages, or subsets of acute leukaemia [140]. The use of the nanoparticles helps to obtain a correct orientation of the antibodies and also in their regeneration.

The incorporation of colloidal gold nanoparticles into hybrid matrices can retain the activity of biomolecules, and enhance the immobilized amount of biomolecules. For instance, Tang et al. [141] have described the use of gold nanoparticles to enhance the signal for the recognition of carcinoembryonic antigens, employing QCMs because of the better immobilization of the antibodies on the surface of the mass sensor. According to the authors, the use of nanoparticles may enhance the immobilization density of bound antibodies and, also, might serve as an intervening "spacer" matrix to extend the immobilized antibody away from the substrate matrix in the mobile phase, resulting in binding sites more accessible to antigens.

Furthermore, the enhancement of the immobilization phenomena by using nanoparticles in biosensing with QCMs has been reported by other authors [142].

10.3.3. Electrochemical Sensors. Electrochemical sensors are widely used for the detection of several biological molecules of clinical interest, by specific recognition through oligonucleotide probes or antibodies immobilized on the detection platform. The captured target is then recognised, in a sandwich format, through its reaction with a secondary antibody or DNA probe connected with easily detectable electroactive nanoparticles. The detection mechanism is based on the electrochemical stripping [143] (usually anodic stripping voltammetry) of the heavy metal based nanoparticles. Depending on the transduction mechanism, the electrochemical sensors can use a potentiometric, amperometric, or conductometric detection.

The antigen-antibody conjugation has been determined by using a biomimetic surface (based on red blood cells) sandwiched between gold nanoparticles deposited on a carbon electrode surface and gold nanoparticles present on the cell surface. These gold nanoparticles have been 
functionalized with mammary cancer 15-3 antibody (antiCA15-3). In the presence of the antigen, the amperometric response decreased with the augmentation of CA15-3 sample concentration [144].

The work of Li et al. [145] describes the use of an electrochemical immunosensor for determining the macrophage migration inhibitory factor (MIF), in the serum of patients with rheumatoid arthritis. The surface of the gold electrode of the sensor was coated with compounds of gold and $\mathrm{TiO}_{2}$ nanoparticles and thionine (NGP-NTiP-Thi), followed by adsorption of anti-MIF antibodies with IgM or IgG1 isotype. The measurements showed considerable levels of sensitivity, selectivity, stability, and long-term maintenance of bioactivity.

A reagentless immunosensor for rapid determination of carbohydrate antigen 19-9 (CA19-9) in human serum was described by Du et al. [146]. This strategy was based on the immobilization of antibody in colloidal gold nanoparticlemodified carbon paste electrode, and the direct electrochemistry of horseradish peroxidase (HRP) that was conjugated to a CA19-9 antibody. The nanoparticles were efficient in preserving the activity of immobilized biomolecules.

A separation-free electrochemical immunosensor for carcinoma antigen-125 (CA125) was proposed based on the immobilization of the CA125 antigen, on colloidal gold nanoparticles, which had been stabilized with cellulose acetate membrane on a glassy carbon electrode. The immunosensor showed good accuracy, acceptable sensitivity, precision, reproducibility, and storage stability [147].

10.3.4. Magnetic Sensors. Kotitz et al. [148] proposed a magnetic relaxation/remanence immunoassay, with a superconducting quantum interference device (SQUID) as magnetic sensor. In this technique, an immobilized target is immersed in a suspension of superparamagnetic nanoparticles bound to antibodies specific to that target. The SQUID detects the magnetic field from the particles bound to the target. An improvement of this technique was achieved by Chemla et al. [149] employing a high-transition temperature SQUID for the ultrasensitive detection of FLAG ${ }^{\circledR}$. The antibody recognizes the FLAG ${ }^{\circledR}$ epitope located on FLAG $^{\circledR}$-tagged fusion proteins. The disadvantage of this detection technique is that it does not allow the simultaneous detection of multiple analytes. Subsequently, Kim and Park [150] described the use of a microfluidic system for the simultaneous detection of multiple antibodies (goat polyclonal anti-mouse IgG $(\mathrm{H}+\mathrm{L}) \mathrm{F}\left(\mathrm{ab}^{\prime}\right)_{2}$ fragments and goat polyclonal anti-rabbit $\left.\operatorname{IgG}(\mathrm{H}+\mathrm{L}) \mathrm{F}\left(\mathrm{ab}^{\prime}\right)_{2}\right)$ attached to magnetic and non-magnetic (fluorescent) nanoparticles by measuring the magnetic force.

The use of magnetoresistance for the biodetection of the antigen-antibody coupling was postulated in 1998 by Baselt et al. [151].

Perez et al. [152], after measuring magnetic relaxation, were able to describe the sensing of magnetic nanoparticles conjugated with anti-adenovirus 5 (ADV-5) or anti-herpes simplex virus 1 (HSV-1) antibodies that, after recognition, agglomerate in the presence of the antigen with, as a consequence, an increase in the relaxation time. The technique could be of potential use for detecting the distribution of HSV and ADV viruses by MRI in vivo.

Multiplexed protein assays are detectable with the commercial equipment, marketed as the Verigene ${ }^{\circledR}$ Reader (Nanosphere Inc., Northbrook, Ill, USA). The protein of interest present in serum is simultaneously attached via hybridization to: magnetic nanoparticles surface functionalized with primary antibodies that recognize the protein of interest; gold nanoparticles functionalized with both secondary antibodies that recognize the protein of interest; and to oliglonucleotides that have different base sequences to identify each protein target in the sample. Once the nanoparticles have sandwiched a protein target, a permanent magnet is used to separate and isolate it from the rest.

The optical detection is based on the capture of the scattered light from the gold-based nanoparticles (scanometric method) [153].

Magnetic nanoparticles coated with DMSA (meso-2,3dimercaptosuccinic acid) and covalently bonded to antihuman cardiac troponin-I have been synthesized, and their biological activity has been evaluated by ELISA and Western Blotting. The stability studies revealed that after 300 days the antibodies on the magnetic nanoparticles retained their biological activity [154].

\section{Antibody Conjugation to Nanoparticles}

Bioconjugation can take place by means of adsorption (at the isoelectrical point of the antibody via electrostatic interaction), by direct covalent linkage between the surface of the nanoparticle and the antibody, or by using adapter molecules. The use of adapter molecules generally involves streptavidin and biotin for the formation of the complex. Biotinylated antibodies are commercially provided. As an example, biotin-labelled polyclonal goat anti-Escherichia coli antibodies have been attached to streptavidin-coated magnetic nanoparticles, and used for the separation and selective quantification of Escherichia coli O157:H7 in ground beef in the presence of other bacteria [155].

Moreover, gelatine and human serum albumin nanoparticles have been surface modified by the covalent attachment of the biotin-binding protein NeutrAvidin ${ }^{\mathrm{TM}}$ enabling the binding of biotinylated anti-HER2 antibodies, showing intracellular specific cell targeting [156]. This group also described the selective targeting of the same nanoparticles conjugated to antibodies, specific for the CD3 antigen on CD3-positive human T-cell leukaemia cells and primary T-lymphocytes [157]. The same biotin-binding protein has been attached to the surface of poly(DL-lactic acid) nanoparticles thanks to the presence of thiol functions on their surface [158].

The clear advantage of using covalent linkages compared to physical adsorption is that the linkage prevents the competitive displacement of the adsorbed antibodies by blood components, which occurs for adsorbed antibodies.

Optimal bioconjugation would involve the covalent attachment of the antibody through the Fc (fragment: crystallizable) region, leaving the antigen-binding site Fab (fragment: antigen binding) region oriented to the medium 
to preserve its full function, and in a ratio of one to one to allow a direct quantification. In addition, the use of a spacer is highly recommended to enhance the probabilities of the antibody finding its corresponding antigen. Hence, oriented covalent binding may increase antibody stability and control the available protein binding sites.

The excellent review of Nobs et al. [159] describes the current methods for attaching targeting ligands to liposomes and nanoparticles.

11.1. Random Antibody Orientation. It is possible to prepare antibody-conjugated nanoparticles, where the antibodies are randomly attached to the surface of the nanoparticle, by using numerous approaches, however the following are the most common.

(1) Formation of a Schiff's base between the primary amine of the antibody and the free aldehyde groups of the glutaraldehyde (bifunctional crosslinker) present on the surface of the amino-functionalized nanoparticle [160].

(2) Formation of an amide bond between the carboxylated nanoparticles and the amino groups of the antibodies, using EDAC or EDC (1-Ethyl-3-(3-dimethylaminopropyl) carbodiimide hydrochloride) as cross-linking agents [161]. Following this procedure, commercial carboxylated magnetic nanoparticles have been covalently attached to polyclonal antibodies used against a sulphonamide-based antibiotic, which can be present in dairy products, for the targeted capture and enrichment of those antimicrobials in milk and hair samples [162]. Invasive epithelial breast tumour cells have also been targeted with polylactic-co-glycolic acid (PLGA) conjugated to a fluorochrome-labelled monoclonal antibody, which recognizes cytokeratins expressed in breast epithelial cell lines and breast tumour cells. Physical adsorption and covalent linkage, with EDC as a linking reagent to form an amide bond, were used for comparison. A binding assay using cell lysate revealed that the recognition properties were preserved only for nanoparticles with the monoclonal antibody adsorbed on their surface [163], corroborating that the correct orientation of the antibody is necessary. Carbodiimide chemistry was used to attach polyclonal antiantibodies to the siglec-7 (CD33-like), and to dye-loaded PLGA nanoparticles, as well as to corroborate the cell internalization pathway through endosomal compartments, by confocal microscopy on mouse embryonic fibroblasts [164].

(3) Formation of an isourea derivative between the hydroxyl surface groups of the nanoparticles and the amino groups of the antibodies, using cyanogen bromide [165].

(4) Poly(lactic acid) nanoparticles have been functionalizated with carboxyl groups and attached to a nucleophile (cysteine or cystamine) to provide thiol groups via an amide bond [166]. Anti-HER2 (Herceptin ${ }^{\circledR}$ ) and antiCD20 (Mabthera ${ }^{\circledR}$ ) monoclonal antibodies were covalently coupled to two kinds of labelled poly(DL-lactic acid) nanoparticles. Thiol groups were introduced on the surface of the nanoparticles by a two-step carbodiimide reaction. The covalent linkage was achieved using a bifunctional crosslinker. In vitro results showed a different cellular localization for both nanoparticles depending on the type of antigenantibody interaction involved [167].

The work of Fuentes et al. [168] describes the biological activity of $\operatorname{IgG}$ anti-horseradish peroxidase attached to activated supports, using the oriented and random coupling chemistry of the antibodies, opening up the spectrum of alternatives for the attachment.

11.2. Oriented Conjugation of the Antibody. It is an advantage if the attachment of the antibody through its Fc region to the nanoparticle is fairly easy, without modifying the antibody activity, stable in a media with high ionic concentration, and allowing a high load of antibody per nanoparticle.

In addition to the use of protein $A$, which interacts specifically with the Fc fragment of the antibody as mentioned above, the literature describes different strategies for the directional attachment of the antibodies with the antigenbinding sites on the Fab portion directed outward from the surface of the nanoparticle and, therefore, available for targeting. These strategies include the surface functionalization of the nanoparticles to render aldehydes, epoxides, thiols, and so forth. It is possible to achieve an oriented conjugation with those functional groups using the following bonds: aldehydes to the lysine-rich region of the antibody; epoxides to the histidine-rich region of the antibody; and thiols to the centre thiol groups of the antibody obtained by reduction. Monoclonal mouse glycosylated antibodies have been conjugated through the Fc region to gold nanoparticles, employing a covalent attachment of a heterofunctional linker (an amide-bonded adipic hydrazide), and an alkane terminating in a dithiol tether via gold-thiol bonds [135]. Hetero-functional epoxy-chelate and immobilization by the sugar chain on amino groups has been demonstrated as another strategy to achieve oriented coupling of antibodies [168].

The other alternative, where a specific orientation of the antibody is not necessary, is the direct attachment of the antibody's fragments (Fabs) to the surface of the nanoparticles.

For this reason, long-circulating (Stealth ${ }^{\circledR}$ ) immunoliposomes were targeted against the B-cell antigen CD19, via a whole HD37 monoclonal antibody (HD37 mAb), versus its Fab' fragment (HD37 Fab') or an HD37-c-myc-CysHis5 single-chain Fv fragment (scFv, HD37-CCH) directed against the same epitope [169]. The coupling through the Fab fragment showed the longest circulation half-life of the conjugated nanoparticles tested, and appeared to be slightly more effective than the others in prolonging survival times.

\section{Conclusions}

Monoclonal antibodies (mAbs), or molecules derived from them, are basic elements for laboratories of clinical diagnosis and research, but are also some of the drugs with the greatest impact in the treatment of different human diseases, including cancer. Currently, there are at least $26 \mathrm{mAbs}$ approved for human therapy, the majority of which are recombinant or humanized antibodies. These antibodies have mainly human sequences in their structure, and a minority of murine 
ones, in order to eliminate or reduce immune response. Yet, the antibodies have a massive therapeutic potential and, currently, 150 are already in different phases of clinical trials and it is likely that, in the near future, many of them will be approved by the regulatory authorities for therapeutic use against different diseases. Currently, nanotechnology is undergoing rapid an enormous development, making a wide variety of applications possible, especially in the field of in vitro and in vivo diagnosis and even in human therapy. The twentieth century was characterized by the vast expansion of the production of mAbs for diagnostic and research techniques; from the final years of that century and in the twenty-first century we have entered the era of mAbs and nanoparticles in human therapy. In this review, we have tried to summarize the most commonly used techniques for the production of these drugs, to show the ones with more advantages, as well as to provide an update of the monoclonal antibodies currently approved for therapeutic use.

\section{Acknowledgments}

The authors would like to thank the Spanish Nanoscience Action NAN200409270-C3-1/2, the Xunta de Galicia (PGIDIT06TMT31402PR), and the Consolider Ingenio 2010 Program (CSD2006-00012) for supporting this study. M. Arruebo would like to acknowledge the support of the 2006 "Ramón y Cajal” Program (order ECI/158/2005). The authors Manuel Arruebo and Mónica Valladares contributed equally to the manuscript.

\section{References}

[1] The Project on Emerging Nanotechnologies, The Woodrow Wilson International Center for Scholars, 2008, http://www.nanotechproject.org/.

[2] The Royal Society and Royal Academy of Engineering, "Nanoscience and nanotechnologies: opportunities and uncertainties," Report, The Royal Society, London, UK, 2004.

[3] C. Bennett, W. H. Konigsberg, and G. M. Edelman, "The covalent structure of a human $\gamma \mathrm{G}$-immunoglobulin. IX. Assignment of asparaginyl and glutaminyl residues," Biochemistry, vol. 9, no. 16, pp. 3181-3188, 1970.

[4] A. M. Lesk and C. Chothia, "Evolution of proteins formed by $\beta$-sheets. II. The core of the immunoglobulin domains," Journal of Molecular Biology, vol. 160, no. 2, pp. 325-342, 1982.

[5] G. W. Siskind, "Idiotype networks and the control of immune responses," Uremia Investigation, vol. 8, no. 3-4, pp. 179-181, 1984.

[6] D. A. Bell, B. Hahn, and G. Harkiss, "Idiotypes, antibodies and immunopathology," Lupus, vol. 1, no. 5, pp. 335-337, 1992.

[7] D. R. Burton, L. Gregory, and R. Jefferis, "Aspects of the molecular structure of IgG subclasses," Monographs in Allergy, vol. 19, pp. 7-35, 1986.

[8] B. Alberts, A. Johnson, D. Bray, et al., Molecular Biology of the Cell, Taylor and Francis, London, UK, 1989.

[9] E. A. Kabat, T. T. Wu, and H. Bilofsky, "Unusual distributions of amino acids in complementarity determining (hypervariable) segments of heavy and light chains of immunoglobulins and their possible roles in specificity of antibody-combining sites," The Journal of Biological Chemistry, vol. 252, no. 19, pp. 6609-6616, 1977.

[10] E. A. Kabat, "The structural basis of antibody complementarity," Advances in Protein Chemistry, vol. 32, pp. 1-75, 1978.

[11] R. K. Jain, "Transport of molecules across tumour vasculature," Cancer Metastasis Reviews, vol. 6, pp. 559-593, 1987.

[12] L. M. Weiner, "Monoclonal antibody therapy of cancer," Seminars in Oncology, vol. 26, no. 5, supplement 14, pp. 4351, 1999.

[13] J. García-Conde and I. Benet, "Tratamiento de los linfomas con anticuerpos monoclonales," Revisiones en Cáncer, vol. 13, no. 4, pp. 153-165, 1999.

[14] S. D. Gorman and M. R. Clark, "Humanisation of monoclonal antibodies for therapy," Seminars in Immunology, vol. 2, no. 6, pp. 457-466, 1990.

[15] S. L. Morrison, "In vitro antibodies: strategies for production and application," Annual Review of Immunology, vol. 10, pp. 239-265, 1992.

[16] M. J. Coloma, A. Hastings, L. A. Wims, and S. L. Morrison, "Novel vectors for the expression of antibody molecules using variable regions generated by polymerase chain reaction," Journal of Immunological Methods, vol. 152, no. 1, pp. 89-104, 1992.

[17] J. J. Trill, A. R. Shatzman, and S. Ganguly, "Production of monoclonal antibodies in COS and CHO cells," Current Opinion in Biotechnology, vol. 6, no. 5, pp. 553-560, 1995.

[18] I. Rasched and E. Oberer, "Ff coliphages: structural and functional relationships," Microbiological Reviews, vol. 50, no. 4, pp. 401-427, 1986.

[19] M. Russel, "Filamentous phage assembly," Molecular Microbiology, vol. 5, no. 7, pp. 1607-1613, 1991.

[20] M. Buchwald, H. Murialdo, and L. Siminovitch, "The morphogenesis of bacteriophage lambda. II. Identification of the principal structural proteins," Virology, vol. 42, no. 2, pp. 390-400, 1970.

[21] W. C. Earnshaw and S. R. Casjens, "DNA packing by the double-stranded DNA bacteriophages," Cell, vol. 21, pp. 319331, 1980.

[22] W. D. Huse, L. Sastry, S. A. Iverson, et al., "Generation of a large combinatorial library of the immunoglobulin repertoire in phage lambda," Science, vol. 246, no. 4935, pp. 1275-1281, 1989.

[23] J. McCafferty, A. D. Griffiths, G. Winter, and D. J. Chiswell, "Phage antibodies: filamentous phage displaying antibody variable domains," Nature, vol. 348, no. 6301, pp. 552-554, 1990.

[24] T. J. Vaughan, A. J. Williams, K. Pritchard, et al., "Human antibodies with sub-nanomolar affinities isolated from a large non-immunized phage display library," Nature Biotechnology, vol. 14, no. 3, pp. 309-314, 1996.

[25] C. Rader and C. F. Barbas III, "Phage display of combinatorial antibody libraries," Current Opinion in Biotechnology, vol. 8, no. 4, pp. 503-508, 1997.

[26] R. Newman, J. Alberts, D. Anderson, et al., “"Primatization" of recombinant antibodies for immunotherapy of human diseases: a macaque/human chimeric antibody against human CD4," Bio/Technology, vol. 10, no. 11, pp. 1455-1460, 1992.

[27] G. Winter and W. J. Harris, "Humanized antibodies," Immunology Today, vol. 14, no. 6, pp. 243-246, 1993.

[28] S. L. Morrison, M. J. Johnson, L. A. Herzenberg, and V. T. Oi, "Chimeric human antibody molecules: mouse antigenbinding domains with human constant region domains," 
Proceedings of the National Academy of Sciences of the United States of America, vol. 81, no. 21, pp. 6851-6855, 1984.

[29] G. L. Boulianne, N. Hozumi, and M. J. Shulman, "Production of functional chimaeric mouse/human antibody," Nature, vol. 312, no. 5995, pp. 643-646, 1984.

[30] H. R. Hoogenboom, J. D. Marks, A. D. Griffiths, and G. Winter, "Building antibodies from their genes," Immunological Reviews, no. 130, pp. 41-68, 1992.

[31] A. F. LoBuglio, R. H. Wheeler, J. Trang, et al., "Mouse/human chimeric monoclonal antibody in man: kinetics and immune response," Proceedings of the National Academy of Sciences of the United States of America, vol. 86, no. 11, pp. 4220-4224, 1989.

[32] M. J. Glennie and P. W. M. Johnson, "Clinical trials of antibody therapy," Immunology Today, vol. 21, no. 8, pp. 403$410,2000$.

[33] M. R. Hurle and M. Gross, "Protein engineering techniques for antibody humanization," Current Opinion in Biotechnology, vol. 5, no. 4, pp. 428-433, 1994.

[34] M. Verhoeyen, C. Milstein, and G. Winter, "Reshaping human antibodies: grafting an antilysozyme activity," Science, vol. 239, no. 4847, pp. 1534-1536, 1988.

[35] E. A. Padlan, "A possible procedure for reducing the immunogenicity of antibody variable domains while preserving their ligand-binding properties," Molecular Immunology, vol. 28, no. 4-5, pp. 489-498, 1991.

[36] M. Brüggemann, G. Winter, H. Waldmann, and M. S. Neuberger, "The immunogenity of chimeric antibodies," Journal of Experimental Medicine, vol. 86, pp. 6709-6713, 1989.

[37] P. S. Andersen, H. Orum, and J. Engberg, "One-step cloning of murine Fab gene fragments independent of IgH isotype for phage display libraries," BioTechniques, vol. 20, no. 3, pp. 340-342, 1996.

[38] M. P. Reddy, C. A. S. Kinney, M. A. Chaikin, et al., "Elimination of Fc receptor-dependent effector functions of a modified IgG4 monoclonal antibody to human CD4," The Journal of Immunology, vol. 164, no. 4, pp. 1925-1933, 2000.

[39] A. Sharma, C. B. Davis, L. A. P. Tobia, et al., "Comparative pharmacodynamics of keliximab and clenoliximab in transgenic mice bearing human CD4," The Journal of Pharmacology and Experimental Therapeutics, vol. 293, no. 1, pp. 33-41, 2000.

[40] J. M. Reichert, "Technology evaluation: lumiliximab, Biogen Idec," Current Opinion in Molecular Therapeutics, vol. 6, no. 6, pp. 675-683, 2004.

[41] A. Plückthum, A. Krebber, C. Krebber, et al., "Producingg antibodies in Escherichia coli: from PCR to fermentation," in Antibody Engineering: A Practical Approach, J. McCafferty, H. R. Hoogenboom, and D. J. Chiswell, Eds., pp. 203-252, Oxford IRL Press, Oxford, UK, 1996.

[42] R. E. Bird, K. D. Hardman, J. W. Jacobson, et al., "Singlechain antigen-binding proteins," Science, vol. 242, no. 4877, pp. 423-426, 1988.

[43] J. S. Huston, D. Levinson, M. Mudgett-Hunter, et al., "Protein engineering of antibody binding sites: recovery of specific activity in an anti-digoxin single-chain Fv analogue produced in Escherichia coli," Proceedings of the National Academy of Sciences of the United States of America, vol. 85, no. 16, pp. 5879-5883, 1988.

[44] R. H. J. Begent, M. J. Verhaar, K. A. Chester, et al., "Clinical evidence of efficient tumor targeting based on single-chain Fv antibody selected from a combinatorial library," Nature Medicine, vol. 2, no. 9, pp. 979-984, 1996.
[45] A. Mayer, E. Tsiompanou, D. O’Malley, et al., "Radioimmunoguided surgery in colorectal cancer using a genetically engineered anti-CEA single-chain Fv antibody," Clinical Cancer Research, vol. 6, no. 5, pp. 1711-1719, 2000.

[46] M. Brennan, P. F. Davison, and H. Paulus, "Preparation of bispecific antibodies by chemical recombination of monoclonal immunoglobulin $\mathrm{G}_{1}$ fragments," Science, vol. 229, no. 4708, pp. 81-83, 1985.

[47] M. J. Glennie, H. M. McBride, A. T. Worth, and G. T. Stevenson, "Preparation and performance of bispecific $\mathrm{F}(\mathrm{ab} \gamma) 2$ antibody containing thioether-linked Fab' $\gamma$ fragments," The Journal of Immunology, vol. 139, no. 7, pp. 2367-2375, 1987.

[48] P. Holliger and G. Winter, "Diabodies: small bispecific antibody fragments," Cancer Immunology Immunotherapy, vol. 45, no. 3-4, pp. 128-130, 1997.

[49] P. Holliger, T. Prospero, and G. Winter, “"Diabodies”: small bivalent and bispecific antibody fragments," Proceedings of the National Academy of Sciences of the United States of America, vol. 90, no. 14, pp. 6444-6448, 1993.

[50] A. A. Kortt, M. Lah, G. W. Oddie, et al., "Single-chain Fv fragments of anti-neuraminidase antibody NC10 containing five- and ten-residue linkers form dimers and with zeroresidue linker a trimer," Protein Engineering, vol. 10, no. 4, pp. 423-433, 1997.

[51] P. J. Hudson, "Recombinant antibody fragments," Current Opinion in Biotechnology, vol. 9, no. 4, pp. 395-402, 1998.

[52] A. Tramontano, E. Bianchi, S. Venturini, F. Martin, A. Pessi, and M. Sollazzo, "The making of the minibody: an engineered beta-protein for the display of conformationally constrained peptides," Journal of Molecular Recognition, vol. 7, no. 1, pp. 9-24, 1994.

[53] S. Hu, L. Shively, A. Raubitschek, et al., "Minibody: a novel engineered anti-carcinoembryonic antigen antibody fragment (single-chain $\mathrm{Fv}_{\mathrm{H}} \mathrm{C}_{\mathrm{H}} 3$ ) which exhibits rapid, highlevel targeting of xenografts," Cancer, vol. 56, pp. 3055-3061, 1996.

[54] E. Li, A. Pedraza, M. Bestagno, S. Mancardi, R. Sanchez, and O. Burrone, "Mammalian cell expression of dimeric small immune proteins (SIP)," Protein Engineering, vol. 10, no. 6, pp. 731-736, 1997.

[55] C. Hamers-Casterman, T. Atarhouch, S. Muyldermans, et al., "Naturally occurring antibodies devoid of light chains," Nature, vol. 363, no. 6428, pp. 446-448, 1993.

[56] V. K. Nguyen, R. Hamers, L. Wyns, and S. Muyldermans, "Loss of splice consensus signal is responsible for the removal of the entire $\mathrm{C}_{\mathrm{H}} 1$ domain of the functional camel IGG2A heavy-chain antibodies," Molecular Immunology, vol. 36, no. 8, pp. 515-524, 1999.

[57] J. Davies and L. Riechmann, "Antibody $\mathrm{V}_{\mathrm{H}}$ domains as small recognition units," Bio/Technology, vol. 13, no. 5, pp. 475479, 1995.

[58] P. Colas, "The eleven-year switch of peptide aptamers," Journal of Biology, vol. 7, no. 1, article 2, 2008.

[59] K. J. Bentley, R. Gewert, and W. J. Harris, "Differential efficiency of expression of humanized antibodies in transient transfected mammalian cells," Hybridoma, vol. 17, no. 6, pp. 559-567, 1998.

[60] W. Zhou, C.-C. Chen, B. Buckland, and J. Aunins, "Fedbatch culture of recombinant NSO myeloma cells with high monoclonal antibody production," Biotechnology and Bioengineering, vol. 55, no. 5, pp. 783-792, 1997.

[61] E. M. Yoo, K. R. Chintalacharuvu, M. L. Penichet, and S. L. Morrison, "Myeloma expression systems," Journal of Immunological Methods, vol. 261, no. 1-2, pp. 1-20, 2002. 
[62] C. K. Borrebaeck, A. C. Malmborg, and M. Ohlin, "Does endogenous glycosylation prevent the use of mouse monoclonal antibodies as cancer therapeutics?" Immunology Today, vol. 14, no. 10, pp. 477-479, 1993.

[63] J. M. McCune, R. Namikawa, H. Kaneshima, L. D. Shultz, M. Lieberman, and I. L. Weissman, "The SCID-hu mouse: murine model for the analysis of human hematolymphoid differentiation and function," Science, vol. 241, no. 4873, pp. 1632-1639, 1988.

[64] D. E. Mosier, R. J. Gulizia, S. M. Baird, and D. B. Wilson, "Transfer of a functional human immune system to mice with severe combined immunodeficiency," Nature, vol. 335, no. 6187, pp. 256-259, 1988.

[65] S. Kamel-Reid and J. E. Dick, "Engraftment of immunedeficient mice with human hematopoietic stem cells," Science, vol. 242, no. 4886, pp. 1706-1709, 1988.

[66] Y. Reisner and S. Dagan, "The Trimera mouse: generating human monoclonal antibodies and an animal model for human diseases," Trends in Biotechnology, vol. 16, no. 6, pp. 242-246, 1998.

[67] L. Zhu, M.-C. van de Lavoir, J. Albanese, et al., "Production of human monoclonal antibody in eggs of chimeric chickens," Nature Biotechnology, vol. 23, no. 9, pp. 1159-1169, 2005.

[68] M. Brüggemann and M. J. Taussig, "Production of human antibody repertoires in transgenic mice," Current Opinion in Biotechnology, vol. 8, no. 4, pp. 455-458, 1997.

[69] L. L. Green, "Antibody engineering via genetic engineering of the mouse: XenoMouse strains are a vehicle for the facile generation of therapeutic human monoclonal antibodies," Journal of Immunological Methods, vol. 231, no. 1-2, pp. 1123, 1999.

[70] N. Lonberg, L. D. Taylor, F. A. Harding, et al., "Antigenspecific human antibodies from mice comprising four distinct genetic modifications," Nature, vol. 368, no. 6474, pp. 856-859, 1994.

[71] S. Magadán, M. Valladares, E. Suarez, et al., "Production of antigen-specific human monoclonal antibodies: comparison of mice carrying IgH/kappa or IgH/kappa/lambda transloci," Biotechniques, vol. 33, no. 3, pp. 680-690, 2002.

[72] A. Molina, M. Valladares, S. Magadán, et al., "The use of transgenic mice for the production of a human monoclonal antibody specific for human CD69 antigen," Journal of Immunological Methods, vol. 282, no. 1-2, pp. 147-158, 2003.

[73] M. Valladares, I. Sanjuán, S. Magadán, A. Molina, F. Sanjuán, and Á. González-Fernández, "H24: a human monoclonal antibody obtained from mice carrying human Ig genes, recognises human myeloid leukaemia and CD5- NonHodgkin's lymphoma," Inmunologia, vol. 23, no. 1, pp. 7-15, 2004.

[74] E. Suárez, S. Magadán, I. Sanjuán, et al., "Rearrangement of only one human IGHV gene is sufficient to generate a wide repertoire of antigen specific antibody responses in transgenic mice," Molecular Immunology, vol. 43, no. 11, pp. 1827-1835, 2006.

[75] B. Díaz, I. Sanjuan, F. Gambón, C. Loureiro, S. Magadán, and Á. González-Fernández, "Generation of a human IgM monoclonal antibody directed against HLA class II molecules: a potential agent in the treatment of haematological malignancies," Cancer Immunology, Immunotherapy, vol. 58, no. 3, pp. 351-360, 2009.

[76] M. L. Linenberger, D. G. Maloney, and I. D. Bernstein, "Antibody-directed therapies for hematological malignancies," Trends in Molecular Medicine, vol. 8, no. 2, pp. 69-76, 2002 .
[77] S. K. Hobbs, W. L. Monsky, F. Yuan, et al., "Regulation of transport pathways in tumor vessels: role of tumor type and microenvironment," Proceedings of the National Academy of Sciences of the United States of America, vol. 95, no. 8, pp. 4607-4612, 1998.

[78] M. Arruebo, R. Fernández-Pacheco, M. R. Ibarra, and J. Santamaría, "Magnetic nanoparticles for drug delivery," Nano Today, vol. 2, no. 3, pp. 22-32, 2007.

[79] S. Burstein and R. Knapp, "Chemotherapy of murine ovarian carcinoma by methotrexate-antibody conjugates," Journal of Medicinal Chemistry, vol. 20, no. 7, pp. 950-952, 1977.

[80] E. Aboud-Pirak, B. Lesur, K. S. P. B. Rao, R. Baurain, A. Trouet, and Y.-J. Schneider, "Cytotoxic activity of daunorubicin or vindesin conjugated to a monoclonal antibody on cultured MCF-7 breast carcinoma cells," Biochemical Pharmacology, vol. 38, no. 4, pp. 641-648, 1989.

[81] M. C. Garnett, "Targeted drug conjugates: principles and progress," Advanced Drug Delivery Reviews, vol. 53, no. 2, pp. 171-216, 2001.

[82] Y. Ikeda and K. Taira, "Ligand-targeted delivery of therapeutic siRNA," Pharmaceutical Research, vol. 23, no. 8, pp. 16311640, 2006.

[83] B. Gupta and V. P. Torchilin, "Monoclonal antibody 2C5modified doxorubicin-loaded liposomes with significantly enhanced therapeutic activity against intracranial human brain U-87 MG tumor xenografts in nude mice," Cancer Immunology, Immunotherapy, vol. 56, no. 8, pp. 1215-1223, 2007.

[84] B. Sun, B. Ranganathan, and S.-S. Feng, "Multifunctional poly(d,l-lactide-co-glycolide)/montmorillonite

(PLGA/MMT) nanoparticles decorated by Trastuzumab for targeted chemotherapy of breast cancer," Biomaterials, vol. 29, no. 4, pp. 475-486, 2008.

[85] I. Steinhauser, B. Spänkuch, K. Strebhardt, and K. Langer, "Trastuzumab-modified nanoparticles: optimisation of preparation and uptake in cancer cells," Biomaterials, vol. 27, no. 28, pp. 4975-4983, 2006.

[86] G. Kou, J. Gao, H. Wang, et al., "Preparation and characterization of paclitaxel-loaded PLGA nanoparticles coated with cationic SM5-1 single-chain antibody," Journal of Biochemistry and Molecular Biology, vol. 40, no. 5, pp. 731-739, 2007.

[87] M. Fujita, B.-S. Lee, N. M. Khazenzon, et al., "Brain tumor tandem targeting using a combination of monoclonal antibodies attached to biopoly( $\beta$-L-malic acid)," Journal of Controlled Release, vol. 122, no. 3, pp. 356-363, 2007.

[88] K. M. Tyner, S. R. Schiffman, and E. P. Giannelis, "Nanobiohybrids as delivery vehicles for camptothecin," Journal of Controlled Release, vol. 95, no. 3, pp. 501-514, 2004.

[89] A. Aigner, "Tumor-targeting nanosystems for the delivery of siRNA," Nanomedicine, vol. 2, no. 4, pp. 569-572, 2007.

[90] M. E. Hayes, D. C. Drummond, D. B. Kirpotin, et al., "Genospheres: self-assembling nucleic acid-lipid nanoparticles suitable for targeted gene delivery," Gene Therapy, vol. 13, no. 7, pp. 646-651, 2006.

[91] J. D. Heidel, Z. Yu, J. Y.-C. Liu, et al., "Administration in nonhuman primates of escalating intravenous doses of targeted nanoparticles containing ribonucleotide reductase subunit M2 siRNA," Proceedings of the National Academy of Sciences of the United States of America, vol. 104, no. 14, pp. 5715-5721, 2007.

[92] J. L. West, R. Drezek, S. Sershen, and N. J. Halas, "Opticallyabsorbing nanoparticles for enhanced tissue repair," US patent no. 6685730; WO03026481, Rice University, Houston, Tex, USA, 2002. 
[93] T. Ashikaga, M. Wada, H. Kobayashi, et al., "Effect of the photocatalytic activity of $\mathrm{TiO}_{2}$ on plasmid DNA," Mutation Research, vol. 466, no. 1, pp. 1-7, 2000.

[94] J. Xu, Y. Sun, J. Huang, et al., "Photokilling cancer cells using highly cell-specific antibody- $\mathrm{TiO}_{2}$ bioconjugates and electroporation," Bioelectrochemistry, vol. 71, no. 2, pp. 217222, 2007.

[95] C. Ogino, K. Kanehira, R. Sasai, S. Sonezaki, and N. Shimizu, "Recognition and effective degradation of $17 \beta$-estradiol by anti-estradiol-antibody-immobilized $\mathrm{TiO}_{2}$ nanoparticles," Journal of Bioscience and Bioengineering, vol. 104, no. 4, pp. 339-342, 2007.

[96] I. H. El-Sayed, X. Huang, and M. A. El-Sayed, "Selective laser photo-thermal therapy of epithelial carcinoma using anti-EGFR antibody conjugated gold nanoparticles," Cancer Letters, vol. 239, no. 1, pp. 129-135, 2006.

[97] V. P. Zharov, K. E. Mercer, E. N. Galitovskaya, and M. S. Smeltzer, "Photothermal nanotherapeutics and nanodiagnostics for selective killing of bacteria targeted with gold nanoparticles," Biophysical Journal, vol. 90, no. 2, pp. 619627, 2006.

[98] L. R. Hirsch, R. J. Stafford, J. A. Bankson, et al., "Nanoshellmediated near-infrared thermal therapy of tumors under magnetic resonance guidance," Proceedings of the National Academy of Sciences of the United States of America, vol. 100, no. 23, pp. 13549-13554, 2003.

[99] S. J. DeNardo, G. L. DeNardo, L. A. Miers, et al., "Development of tumor targeting bioprobes ( ${ }^{111} \mathrm{In}$-chimeric L6 monoclonal antibody nanoparticles) for alternating magnetic field cancer therapy," Clinical Cancer Research, vol. 11, no. 19, pp. 7087s-7092s, 2005.

[100] F. Tsagkogeorgas, M. Ochsenkühn-Petropoulou, R. Niessner, and D. Knopp, "Encapsulation of biomolecules for bioanalytical purposes: preparation of diclofenac antibody-doped nanometer-sized silica particles by reverse micelle and sol-gel processing," Analytica Chimica Acta, vol. 573-574, pp. 133137, 2006.

[101] Z. Cui, S.-J. Han, D. P. Vangasseri, and L. Huang, "Immunostimulation mechanism of LPD nanoparticle as a vaccine carrier," Molecular Pharmaceutics, vol. 2, no. 1, pp. 22-28, 2005.

[102] M. J. Joralemon, N. L. Smith, D. Holowka, B. Baird, and K. L. Wooley, "Antigen-decorated shell cross-linked nanoparticles: synthesis, characterization, and antibody interactions," Bioconjugate Chemistry, vol. 16, no. 5, pp. 1246-1256, 2005.

[103] X. Wang, T. Uto, T. Akagi, M. Akashi, and M. Baba, "Poly $(\gamma-$ glutamic acid) nanoparticles as an efficient antigen delivery and adjuvant system: potential for an AIDS vaccine," Journal of Medical Virology, vol. 80, no. 1, pp. 11-19, 2008.

[104] A. Debin, R. Kravtzoff, J. V. Santiago, et al., "Intranasal immunization with recombinant antigens associated with new cationic particles induces strong mucosal as well as systemic antibody and CTL responses," Vaccine, vol. 20, no. 21-22, pp. 2752-2763, 2002.

[105] M. Amidi, S. G. Romeijn, J. C. Verhoef, et al., " $N$-trimethyl chitosan (TMC) nanoparticles loaded with influenza subunit antigen for intranasal vaccination: biological properties and immunogenicity in a mouse model," Vaccine, vol. 25, no. 1, pp. 144-153, 2007.

[106] D. Lamalle-Bernard, S. Munier, C. Compagnon, et al., "Coadsorption of HIV-1 p24 and gp120 proteins to surfactant-free anionic PLA nanoparticles preserves antigenicity and immunogenicity," Journal of Controlled Release, vol. 115, no. 1, pp. 57-67, 2006.
[107] B. Liu, F. Conrad, M. R. Cooperberg, D. B. Kirpotin, and J. D. Marks, "Mapping tumor epitope space by direct selection of single-chain Fv antibody libraries on prostate cancer cells," Cancer Research, vol. 64, no. 2, pp. 704-710, 2004.

[108] J. Kandzia, M. J. D. Anderson, and W. Müller-Ruchholtz, "Cell separation by antibody-coupled magnetic microspheres and their application in conjunction with monoclonal HLA-antibodies," Journal of Cancer Research and Clinical Oncology, vol. 101, no. 1, pp. 165-170, 1981.

[109] L. Illum, P. D. E. Jones, R. W. Baldwin, and S. S. Davis, “Tissue distribution of poly(hexyl 2- cyanoacrylate) nanoparticles coated with monoclonal antibodies in mice bearing human tumor xenografts," The Journal of Pharmacology and Experimental Therapeutics, vol. 230, no. 3, pp. 733-736, 1984.

[110] W. Kemmner, G. Moldenhauer, P. Schlag, and R. Brossmer, "Separation of tumor cells from a suspension of dissociated human colorectal carcinoma tissue by means of monoclonal antibody-coated magnetic beads," Journal of Immunological Methods, vol. 147, no. 2, pp. 197-200, 1992.

[111] C. S. Owen and N. L. Sykes, "Magnetic labelling and cell sorting," Journal of Immunological Methods, vol. 73, pp. 4148, 1984.

[112] J. P. Mach, F. Buchegger, M. Forni, et al., "Use of radiolabeled monoclonal anti-CEA antibodies for the detection of human carcinomas by external photoscanning and tomoscintigraphy," Immunol Today, vol. 2, pp. 239-249, 1981.

[113] A. Natarajan, C.-Y. Xiong, C. Gruettner, G. L. DeNardo, and S. J. DeNardo, "Development of multivalent radioimmunonanoparticles for cancer imaging and therapy," Cancer Biotherapy and Radiopharmaceuticals, vol. 23, no. 1, pp. 8291, 2008.

[114] J. C. Richardson, R. W. Bowtell, K. Mäder, and C. D. Melia, "Pharmaceutical applications of magnetic resonance imaging (MRI)," Advanced Drug Delivery Reviews, vol. 57, no. 8, pp. 1191-1209, 2005.

[115] T. Suwa, S. Ozawa, M. Ueda, N. Ando, and M. Kitajima, "Magnetic resonance imaging of esophageal squamous cell carcinoma using magnetite particles coated with antiepidermal growth factor receptor antibody," International Journal of Cancer, vol. 75, no. 4, pp. 626-634, 1998.

[116] T. Koblas, P. Girman, Z. Berkova, et al., "Magnetic resonance imaging of intrahepatically transplanted islets using paramagnetic beads," Transplantation Proceedings, vol. 37, no. 8, pp. 3493-3495, 2005.

[117] P. M. Winter, K. Cai, J. Chen, et al., "Targeted PARACEST nanoparticle contrast agent for the detection of fibrin," Magnetic Resonance in Medicine, vol. 56, no. 6, pp. 13841388, 2006.

[118] H.-J. Weinmann, W. Ebert, B. Misselwitz, and H. SchmittWillich, "Tissue-specific MR contrast agents," European Journal of Radiology, vol. 46, no. 1, pp. 33-44, 2003.

[119] X. Liu, Q. Dai, L. Austin, et al., "A one-step homogeneous immunoassay for cancer biomarker detection using gold nanoparticle probes coupled with dynamic light scattering," Journal of the American Chemical Society, vol. 130, no. 9, pp. 2780-2782, 2008.

[120] F. Velge-Roussel, P. Breton, X. Guillon, et al., "Immunochemical characterization of antibody-coated nanoparticles," Experientia, vol. 52, no. 8, pp. 803-806, 1996.

[121] S. Kubitschko, J. Spinke, T. Bruckner, S. Pohl, and N. Oranth, "Sensitivity enhancement of optical immunosensors with nanoparticles," Analytical Biochemistry, vol. 253, no. 1, pp. 112-122, 1997. 
[122] A. J. Haes, D. A. Stuart, S. Nie, and R. P. Van Duyne, "Using solution-phase nanoparticles, surface-confined nanoparticle arrays and single nanoparticles as biological sensing platforms," Journal of Fluorescence, vol. 14, no. 4, pp. 355-367, 2004.

[123] A. Tsourkas, V. R. Shinde-Patil, K. A. Kelly, et al., "In vivo imaging of activated endothelium using an anti-VCAM-1 magnetooptical probe," Bioconjugate Chemistry, vol. 16, no. 3, pp. 576-581, 2005.

[124] J. Yguerabide and E. E. Yguerabide, "Light-scattering submicroscopic particles as highly fluorescent analogs and their use as tracer labels in clinical and biological applications. I. Theory," Analytical Biochemistry, vol. 262, no. 2, pp. 137-156, 1998.

[125] K. Sokolov, M. Follen, J. Aaron, et al., "Real-time vital optical imaging of precancer using anti-epidermal growth factor receptor antibodies conjugated to gold nanoparticles," Cancer Research, vol. 63, no. 9, pp. 1999-2004, 2003.

[126] D. Yelin, D. Oron, S. Thiberge, E. Moses, and Y. Silberberg, "Multiphoton plasmon-resonance microscopy," Optics Express, vol. 11, no. 12, pp. 1385-1391, 2003.

[127] C. B. Raub, E. J. Orwin, and R. Haskell, "Immunogold labeling to enhance contrast in optical coherence microscopy of tissue engineered corneal constructs," Journal of Biomechanical Engineering, vol. 125, pp. 1-6, 2003.

[128] L. R. Hirsch, J. B. Jackson, A. Lee, N. J. Halas, and J. L. West, "A whole blood immunoassay using gold nanoshells," Analytical Chemistry, vol. 75, no. 10, pp. 2377-2381, 2003.

[129] Y. Cui, B. Ren, J.-L. Yao, R.-A. Gu, and Z.-Q. Tian, "Synthesis of AgcoreAushell bimetallic nanoparticles for immunoassay based on surface-enhanced Raman spectroscopy," Journal of Physical Chemistry B, vol. 110, no. 9, pp. 4002-4006, 2006.

[130] H. Sun, A. M. Scharff-Poulsen, H. Gu, et al., "Phosphate sensing by fluorescent reporter proteins embedded in polyacrylamide nanoparticles," ACS Nano, vol. 2, no. 1, pp. 1924, 2008.

[131] K. Fu, J. Sun, L. R. Bickford, et al., "Measurement of immunotargeted plasmonic nanoparticles' cellular binding: a key factor in optimizing diagnostic efficacy," Nanotechnology, vol. 19, no. 4, Article ID 045103, 6 pages, 2008.

[132] I. H. El-Sayed, X. Huang, and M. A. El-Sayed, "Surface plasmon resonance scattering and absorption of anti-EGFR antibody conjugated gold nanoparticles in cancer diagnostics: applications in oral cancer," Nano Letters, vol. 5, no. 5, pp. 829-834, 2005.

[133] R. Tanaka, T. Yuhi, N. Nagatani, et al., "A novel enhancement assay for immunochromatographic test strips using gold nanoparticles," Analytical and Bioanalytical Chemistry, vol. 385, no. 8, pp. 1414-1420, 2006.

[134] M. Arruebo, R. Fernández-Pacheco, B. Velasco, et al., "Antibody-functionalized hybrid superparamagnetic nanoparticles," Advanced Functional Materials, vol. 17, no. 9, pp. 1473-1479, 2007.

[135] S. Kumar, J. Aaron, and K. Sokolov, "Directional conjugation of antibodies to nanoparticles for synthesis of multiplexed optical contrast agents with both delivery and targeting moieties," Nature Protocols, vol. 3, no. 2, pp. 314-320, 2008.

[136] S.-Z. Yao and Z.-H. Mo, "Frequency properties of a piezoelectric quartz crystal in solutions and application to total salt determination," Analytica Chimica Acta, vol. 193, pp. 97-105, 1987.

[137] H. Wang, C. Lei, J. Li, Z. Wu, G. Shen, and R. Yu, "A piezoelectric immunoagglutination assay for Toxoplasma gondii antibodies using gold nanoparticles," Biosensors and Bioelectronics, vol. 19, no. 7, pp. 701-709, 2004.

[138] Y. Ding, J. Liu, X. Jin, H. Lu, G. Shen, and R. Yu, "PolyL-lysine/hydroxyapatite/carbon nanotube hybrid nanocomposite applied for piezoelectric immunoassay of carbohydrate antigen 19-9," Analyst, vol. 133, no. 2, pp. 184-190, 2008.

[139] R. De Palma, G. Reekmans, W. Laureyn, G. Borghs, and G. Maes, "The optimization of magnetosandwich assays for the sensitive and specific detection of proteins in serum," Analytical Chemistry, vol. 79, no. 19, pp. 7540-7548, 2007.

[140] H. Zeng, H. Wang, F. Chen, et al., "Development of quartz-crystal-microbalance-based immunosensor array for clinical immunophenotyping of acute leukemias," Analytical Biochemistry, vol. 351, no. 1, pp. 69-76, 2006.

[141] D.-Q. Tang, D.-J. Zhang, D.-Y. Tang, and H. Ai, "Amplification of the antigen-antibody interaction from quartz crystal microbalance immunosensors via back-filling immobilization of nanogold on biorecognition surface," Journal of Immunological Methods, vol. 316, no. 1-2, pp. 144-152, 2006.

[142] H. Wang, J. Wu, J. Li, Y. Ding, G. Shen, and R. Yu, "Nanogold particle-enhanced oriented adsorption of antibody fragments for immunosensing platforms," Biosensors and Bioelectronics, vol. 20, no. 11, pp. 2210-2217, 2005.

[143] J. Wang, Instrumentation for Stripping Analysis in Analytical Instrumentation Handbook, Marcel Dekker, New York, NY, USA, 2nd edition, 1997.

[144] D. Tang, R. Yuan, and Y. Chai, "Biochemical and immunochemical characterization of the antigen-antibody reaction on a non-toxic biomimetic interface immobilized red blood cells of crucian carp and gold nanoparticles," Biosensors and Bioelectronics, vol. 22, no. 6, pp. 1116-1120, 2007.

[145] S. Li, R. Zhang, P. Li, et al., "Development of a novel method to measure macrophage migration inhibitory factor (MIF) in sera of patients with rheumatoid arthritis by combined electrochemical immunosensor," International Immunopharmacology, vol. 8, no. 6, pp. 859-865, 2008.

[146] D. Du, X. Xu, S. Wang, and A. Zhang, "Reagentless amperometric carbohydrate antigen 19-9 immunosensor based on direct electrochemistry of immobilized horseradish peroxidase," Talanta, vol. 71, no. 3, pp. 1257-1262, 2007.

[147] L. Wu, J. Chen, D. Du, and H. Ju, "Electrochemical immunoassay for CA125 based on cellulose acetate stabilized antigen/colloidal gold nanoparticles membrane," Electrochimica Acta, vol. 51, no. 7, pp. 1208-1214, 2006.

[148] R. Kotitz, T. Bunte, W. Weitschies, and L. Trahms, "Superconducting quantum interference device-based magnetic nanoparticle relaxation measurement as a novel tool for the binding specific detection of biological binding reactions," Journal of Applied Physics, vol. 81, pp. 4317-4317, 1997.

[149] Y. R. Chemla, H. L. Grossman, Y. Poon, et al., "Ultrasensitive magnetic biosensor for homogeneous immunoassay," Proceedings of the National Academy of Sciences of the United States of America, vol. 97, no. 26, pp. 14268-14272, 2000.

[150] K. S. Kim and J.-K. Park, "Magnetic force-based multiplexed immunoassay using superparamagnetic nanoparticles in microfluidic channel," Lab on a Chip, vol. 5, no. 6, pp. 657664, 2005.

[151] D. R. Baselt, G. U. Lee, M. Natesan, S. W. Metzger, P. E. Sheehan, and R. J. Colton, "A biosensor based on magnetoresistance technology," Biosensors and Bioelectronics, vol. 13, no. 7-8, pp. 731-739, 1998.

[152] J. M. Perez, F. J. Simeone, Y. Saeki, L. Josephson, and R. Weissleder, "Viral-induced self-assembly of magnetic 
nanoparticles allows the detection of viral particles in biological media," Journal of the American Chemical Society, vol. 125, no. 34, pp. 10192-10193, 2003.

[153] T. A. Taton, C. A. Mirkin, and R. L. Letsinger, "Scanometric DNA array detection with nanoparticle probes," Science, vol. 289, no. 5485, pp. 1757-1760, 2000.

[154] S. Zhang, Z. Bian, C. Gu, et al., "Preparation of antihuman cardiac troponin I immunomagnetic nanoparticles and biological activity assays," Colloids and Surfaces B, vol. 55, no. 2, pp. 143-148, 2007.

[155] M. Varshney, L. Yang, X.-L. Su, and Y. Li, "Magnetic nanoparticle-antibody conjugates for the separation of Escherichia coli O157:H7 in ground beef," Journal of Food Protection, vol. 68, no. 9, pp. 1804-1811, 2005.

[156] H. Wartlick, K. Michaelis, S. Balthasar, K. Strebhardt, J. Kreuter, and K. Langer, "Highly specific HER2-mediated cellular uptake of antibody-modified nanoparticles in tumour cells," Journal of Drug Targeting, vol. 12, no. 7, pp. 461-471, 2004.

[157] N. Dinauer, S. Balthasar, C. Weber, J. Kreuter, K. Langer, and $\mathrm{H}$. von Briesen, "Selective targeting of antibody-conjugated nanoparticles to leukemic cells and primary T-lymphocytes," Biomaterials, vol. 26, no. 29, pp. 5898-5906, 2005.

[158] L. Nobs, F. Buchegger, R. Gurny, and E. Allémann, "Poly(lactic acid) nanoparticles labeled with biologically active Neutravidin $^{\mathrm{TM}}$ for active targeting," European Journal of Pharmaceutics and Biopharmaceutics, vol. 58, no. 3, pp. 483-490, 2004.

[159] L. Nobs, F. Buchegger, R. Gurny, and E. Allémann, "Current methods for attaching targeting ligands to liposomes and nanoparticles," Journal of Pharmaceutical Sciences, vol. 93, no. 8, pp. 1980-1992, 2004.

[160] G. F. Bickerstaff, Immobilization of Enzymes and Cells, Methods in Biotechnology, Humana Press, New York, NY, USA, 1997.

[161] T. L. Goodfriend, L. Levine, and G. D. Fasman, "Antibodies to bradykinin and angiotensin: a use of carbodiimides in immunology," Science, vol. 144, no. 3624, pp. 1344-1346, 1964.

[162] H. Font, J. Adrian, R. Galve, et al., "Immunochemical assays for direct sulfonamide antibiotic detection in milk and hair samples using antibody derivatized magnetic nanoparticles," Journal of Agricultural and Food Chemistry, vol. 56, no. 3, pp. 736-743, 2008.

[163] P. Kocbek, N. Obermajer, M. Cegnar, J. Kos, and J. Kristl, "Targeting cancer cells using PLGA nanoparticles surface modified with monoclonal antibody," Journal of Controlled Release, vol. 120, no. 1-2, pp. 18-26, 2007.

[164] C. J. Scott, W. M. Marouf, D. J. Quinn, et al., "Immunocolloidal targeting of the endocytotic siglec-7 receptor using peripheral attachment of siglec-7 antibodies to poly(lactideco-glycolide) nanoparticles," Pharmaceutical Research, vol. 25, no. 1, pp. 135-146, 2008.

[165] S. C. March, I. Parikh, and P. Cuatrecasas, "A simplified method for cyanogen bromide activation of agarose for affinity chromatography," Analytical Biochemistry, vol. 60, no. 1, pp. 149-152, 1974.

[166] L. Nobs, F. Buchegger, R. Gurny, and E. Allémann, "Surface modification of poly(lactic acid) nanoparticles by covalent attachment of thiol groups by means of three methods," International Journal of Pharmaceutics, vol. 250, no. 2, pp. 327-337, 2003.
[167] A. Cirstoiu-Hapca, L. Bossy-Nobs, F. Buchegger, R. Gurny, and F. Delie, "Differential tumor cell targeting of antiHER2 (Herceptin ${ }^{\circledR}$ ) and anti-CD20 (Mabthera ${ }^{\circledR}$ ) coupled nanoparticles," International Journal of Pharmaceutics, vol. 331, no. 2, pp. 190-196, 2007.

[168] M. Fuentes, C. Mateo, J. M. Guisán, and R. FernándezLafuente, "Preparation of inert magnetic nano-particles for the directed immobilization of antibodies," Biosensors and Bioelectronics, vol. 20, no. 7, pp. 1380-1387, 2005.

[169] W. W. K. Cheng and T. M. Allen, "Targeted delivery of anti-CD19 liposomal doxorubicin in B-cell lymphoma: a comparison of whole monoclonal antibody, Fab' fragments and single chain Fv," Journal of Controlled Release, vol. 126, no. 1, pp. 50-58, 2008. 

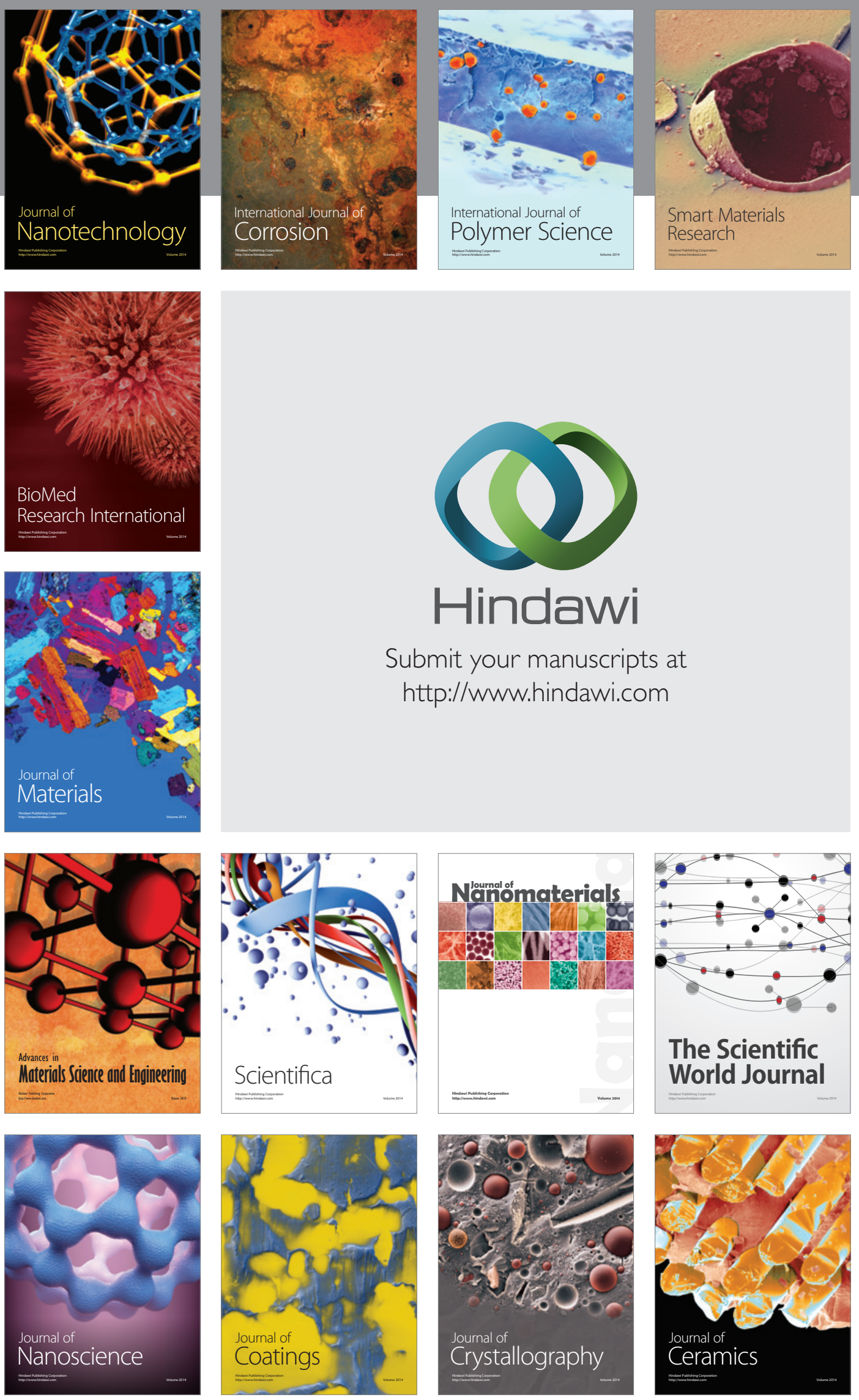

The Scientific World Journal

Submit your manuscripts at

http://www.hindawi.com

\section{World Journal}

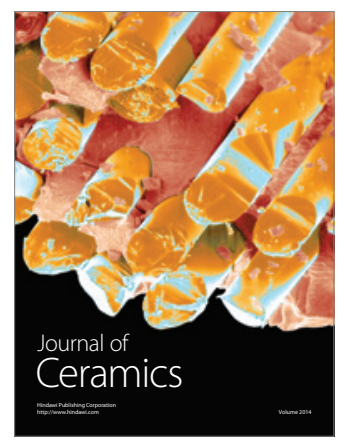

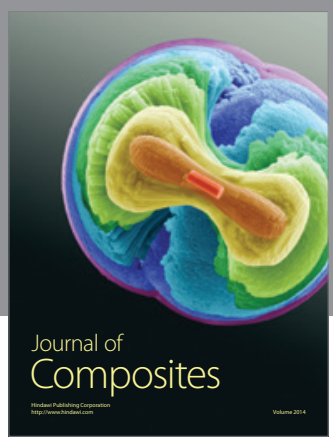
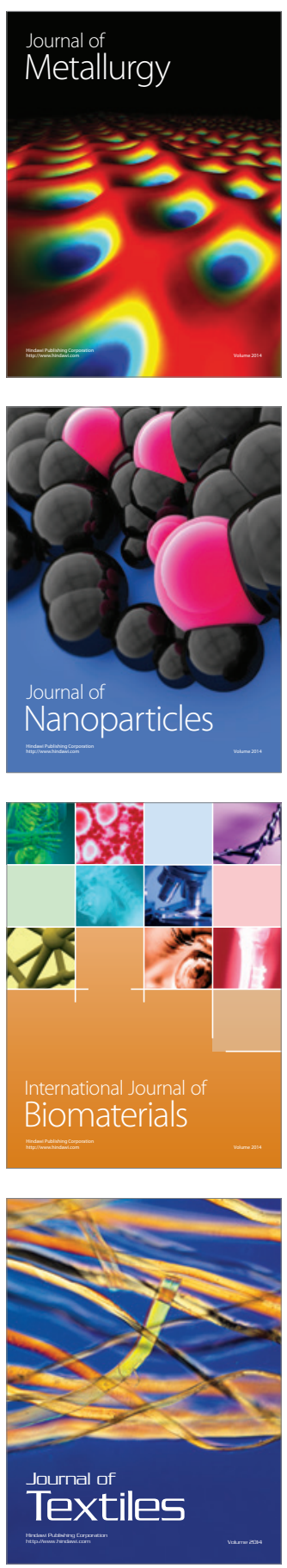